University of Pennsylvania Carey Law School

Penn Law: Legal Scholarship Repository

Faculty Scholarship at Penn Law

1999

\title{
Waiting for the Omelet to Set: Match-Specific Assets and Minority Oppression in the Close Corporation
}

\author{
Edward B. Rock \\ University of Pennsylvania Carey Law School \\ Michael L. Wachter \\ University of Pennsylvania Carey Law School
}

Follow this and additional works at: https://scholarship.law.upenn.edu/faculty_scholarship

Part of the Business Administration, Management, and Operations Commons, Business Organizations Law Commons, Contracts Commons, Corporate Finance Commons, Finance Commons, Finance and

Financial Management Commons, Law and Economics Commons, and the Securities Law Commons

\section{Repository Citation}

Rock, Edward B. and Wachter, Michael L., "Waiting for the Omelet to Set: Match-Specific Assets and Minority Oppression in the Close Corporation" (1999). Faculty Scholarship at Penn Law. 644.

https://scholarship.law.upenn.edu/faculty_scholarship/644

This Article is brought to you for free and open access by Penn Law: Legal Scholarship Repository. It has been accepted for inclusion in Faculty Scholarship at Penn Law by an authorized administrator of Penn Law: Legal Scholarship Repository. For more information, please contact PennlawIR@law.upenn.edu. 


\title{
Waiting for the Omelet to Set: Match-Specific Assets and Minority Oppression in Close Corporations
}

\author{
Edward B. Rock \& Michael L. Wachter*
}

I. INTRODUCTION

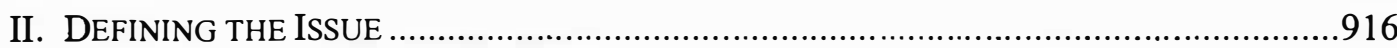

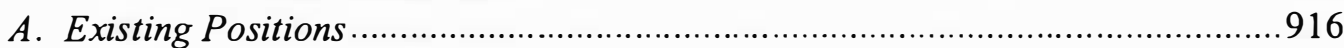

B. Our Position and the Silicon Valley Start-Up .................................................918

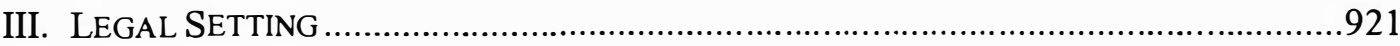

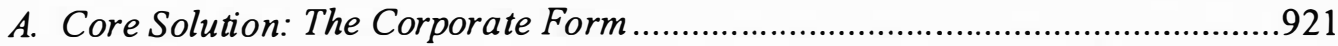

B. Majority Opportunism and the Remedy for "Minority Oppression " .................923

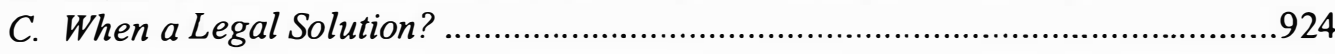

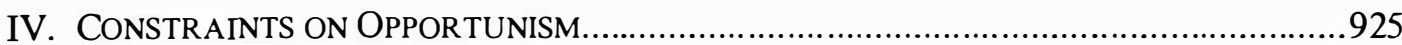

A. The Employment Relationship and Investments in Match ................................925

B. Close Corporation: Non-Legal Constraints on Opportunism .............................927

V. The Proper Judicial Role IN THE THReE CASES..................................................929

A. Case A: Employment at Will as Minority Oppression? ......................................930

B. Case B: Stock Buybacks as Minority Oppression? ...........................................934

C. The Courts' Comparative Advantage: Do Cases A and B Differ? .....................938

D. Case C: Is the Sale of Control for a Premium a Non Pro Rata Distribution? ...942

E. Minority Shareholders 'Informational Rights ...............................................945

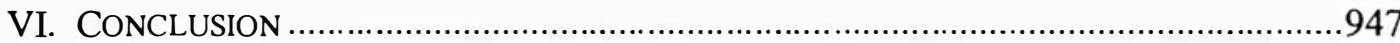

\section{INTRODUCTION}

Closely held corporations ("close corporations") form an important subset of corporations with concentrated ownership. ${ }^{1}$ The category includes an interesting variety of enterprises, including the traditional "mom and pop" businesses, high-tech start-ups,

* We are grateful for comments from Howard Chang, Zohar Goshen, Lawrence Hamermesh, Peter Huang, Michael Klausner, Dale Oesterle, Steven Rosenblum, David Skeel, Lynn Stout, Eric Talley, Robert Thompson, and participants in presentations at the National Bureau of Economic Research (NBER) Conference on Concentrated Ownership, University of Colorado, University of Pennsylvania, Georgetown, and the American Law and Economics Association. As part of the NBER conference, this paper will also appear as a chapter in the forthcoming book CONCENTRATED CORPORATE OWNERSHIP (Randall Morck ed. 2000).

1. Closely held corporations are typically defined as corporations for which there is no public market for shares and, sometimes, no market at all. An altemative and largely co-extensive definition is corporations with few (typically defined as less than 25) shareholders. See, e.g., AMERICAN LAW INSTITUTE, PRINCIPLES OF CORPORATE GOVERNANCE: ANALYSIS AND RECOMMENDATIONS $§ 1.06$ (1994) [hereinafter ALI]. 
and mature publicly held corporations post leveraged buyouts. More generally, close corporations are important because of their number and because even the largest publicly held corporations often start out as closely held corporations. As such, close corporations are incubators for tomorrow's publicly held corporations.

Two sets of problems have arisen repeatedly in closely held corporations, but only rarely in publicly held firms. The first, now resolved, revolved around the enforceability of attempts by participants to tailor the terms set by the general corporation law. Because states historically have provided one corporation law for all corporations, participants in closely held corporations have often tried to modify the statutory structure by contract to serve their needs. These variations have raised the question of the extent to which parties can contract out of the rules provided by the statute. The evolution toward greater flexibility was long, and at times, hard fought, but it no longer is a central issue. Today, participants in the close corporation can largely tailor its terms to their purposes.

The second set of problems, and the focus of this Article, falls under the caption of "protection of minority shareholders." To what extent should the law provide protection to minority shareholders from "oppression" by majority shareholders, beyond what the parties have contracted for? This set of questions, unlike the first set, remains alive and controversial. It has been the subject of an enormous amount of judicial and legislative effort, much of which has been devoted to expanding the rights of minority shareholders. The questions raised go to the very core of what corporations are about.

There are several repeated scenarios that raise the issue of "minority oppression." Consider the following:

Case A: There is a falling out between the majority shareholder, Major, and the minority shareholder, Minor, both of whom work in the business. Major fires Minor, who then can either hold on to his shares, which pay no dividends (all distributions are through excessive salaries), or sell them back to the firm for whatever the majority shareholder is willing to offer. A variant arises when there are three equal shareholders, $\mathrm{A}, \mathrm{B}$, and $\mathrm{C}$. After a falling-out, $\mathrm{A}$ and $\mathrm{B}$ gang up on $C$ and fire him, at which point he is left with shares that pay no dividends and which only the firm is willing to buy. ${ }^{2}$

Case B: The majority shareholder or group of shareholders enter into a transaction with the firm, in which, for example, the firm buys back a portion of the majority shareholders' shares without making the opportunity available to the minority shareholders. ${ }^{3}$ Easier variants of this scenario include the full range of transactions of controlling shareholders with the firm, including compensation, selling and buying property, and diversion of corporate opportunities. ${ }^{4}$ More difficult variants include the situation in which the majority shareholder takes advantage of opportunities which are not clearly corporate opportunities, such as developing a more liquid market for shares in

2. See, e.g., Wilkes v. Springside Nursing Home, Inc., 353 N.E.2d 657 (Mass. 1976); In re Topper, 433 N.Y.S.2d 359 (N.Y. Sup. Ct. 1980).

3. Classic examples are Donahue v. Rodd Electrotype Co., 328 N.E.2d 505 (Mass. 1975) and Nixon v. Blackwell, 626 A.2d 1366 (Del. 1993).

4. See, e.g., Crosby v. Beam, 548 N.E.2d 217 (Ohio 1989); Alaska Plastics, Inc. v. Coppock, 621 P.2d 270 (Alaska 1980). 
which the minority shareholders would like to participate, but are not offered the opportunity. ${ }^{5}$

Case C: The majority shareholder sells its majority (controlling) stake to a third party without giving the minority shareholder an opportunity to participate.

This Article addresses the question of what, if anything, the courts should do for the minority shareholders in cases where the parties have not provided for the problem by contract. ${ }^{6}$ Our basic answer is that courts should not do anything except enforce the participants' contracts and vigorously prevent non pro rata distributions to shareholders. This second principle provides a guide to the expansion of minority shareholder protection against "oppression."7

We proceed as follows. First, we make a fundamental break with the traditional legal treatment of the problem of "minority oppression" by rejecting the analogy between close corporations and partnerships, and the intuitions and implications that flow from it. We also show that the alternative argument, which emphasizes the low agency costs of close corporations, needs to be expanded upon to explain the Silicon Valley type of startup close corporation. Second, we illustrate that the close corporation form is best suited to companies that require extensive investments in match assets. In such cases, the close corporation acts as an incubator and the lock-in is a benefit, not a cost. Low agency costs are more likely a result of the choice of forms and not the reason the form is adopted in the first instance. Third, we argue that the problem of minority oppression combines two fundamentally separate problems: in the employment context, the issue raised by the "employment at will" doctrine; and the quite separate problem of controlling shareholder attempts to make non pro rata distributions of firm assets. Building on an earlier analysis of employment at will, we then show that the same rule of judicial non-intervention that govems the employment relationship solves closely similar problems in the close corporation context. This rule, combined with vigorous judicial enforcement of the rule of no non pro rata distributions, including ancillary enforcement of minority shareholder informational rights, and limitations on the ability of control shareholders to sell shares to the firm, allows the close corporation to maximize the value of its match assets. We conclude by drawing the implications of the analysis for a larger theory of close corporations.

5. See Jones v. Ahmanson \& Co., 460 P.2d 464 (Cal. 1969).

6. For a very interesting and important game theoretic analysis that arrives at many of the same points as we do but from a different direction, see Jason Johnston, Opting In and Opting Out: Bargaining for Fiduciary Duties in Cooperative Ventures, 70 WASH. U. L.Q. 291 (1992). Other important treatments that overlap with ours are Frank H. EASTERBROOK \& DANIEL R. FISCHEL, THE ECONOMIC STRUCTURE OF CORPORATE LAW 228-52 (1991), and Charles R. O'Kelley, Filling the Gaps in the Close Corporation Contract: A Transaction Cost Analysis, 87 Nw. U. L. REv. 216 (1992).

7. There is a third problem which is not normally thought of as a "close corporation problem" but which is, namely, "piercing the corporate veil." This is the issue of when a creditor can "pierce the corporate veil" of limited liability in order to reach the assets of the shareholders. Although formally a question that arises in both publicly held and close corporations, the issue arises only in close corporations-in the United States, at least. This issue is, however, beyond the scope of the article. 


\section{DEFINING THE ISSUE}

There are two types of structures that fall under the heading of close corporation. One is the traditional close corporation, often small scale and family owned. The other is what we will call the "Silicon Valley start-up."8 Several traits typically characterize the closely held firm: there are few shareholders; no public market for the shares; and a substantial overlap between suppliers of capital and suppliers of labor. Due to the overlap between managers and shareholders and the absence of public markets, the shareholder/managers of the close corporation are in continuous contact with each other. The lack of a public market causes the parties to be locked into their investments to a much greater extent than in either the partnership or the publicly traded corporation. Because the majority shareholders elect the directors and control the management of the corporation, minority shareholders are particularly vulnerable if there is a falling-out with the majority.

\section{A. Existing Positions}

In their famous and influential article, John Hetherington and Michael Dooley expressed the intuition that lies at the heart of the evolution of minority shareholders' remedies for "oppression": that, in all important respects, "the close corporation is the functional equivalent of the partnership." form over the partnership form simply to take advantage of limited liability. The problem with close corporation law, they argue, is that despite this functional equivalence, shareholders cannot exit their investment as easily as partners who always have the power to trigger a buyout by dissolving the partnership "by the express will of any partner at any time." 10 To them, the difficulty of exit is a flaw in the legal structure. Their

8. Today, substantial literature exists on the structure and governance of venture capital start-ups. See Christopher B. Barry et al., The Role of Venture Capital in the Creation of Public Companies: Evidence from the Going-Public Process, 27 J. FIN. ECON. 447, 456 (1990); Paul A. Gompers, Optimal Investment, Monitoring, and the Staging of Venture Capital, 50 J. FIN. 1461 (1995); Michael Gorman \& William A. Sahlman, What Do Venture Capitalists Do?, 4 J. BUS. VENTURING 231 (1989); Josh Lerner, Venture Capitalists and the Decision to Go Public, 35 J. FIN. ECON. 293 (1994); Josh Lemer, Venture Capitalists and the Oversight of Private Firms, 50 J. FIN. 301 (1995); William A. Sahlman, The Structure and Governance of Venture-Capital Organizations, 27 J. FIN. ECON. 473, 493 (1990); Josh Lemer \& Robert P. Merges, The Control of Strategic Alliances: An Empirical Analysis of Biotechnology Collaborations (Sept. 1996) (unpublished manuscript, on file with the authors). For a more comprehensive description of the "private equity" market, see GEORGE W. FEnN, ET AL., The Economics of THE PRIVATE EQuity MARKeT (Board of Govemors of the Fed. Reserve Staff Study No. 168, Dec. 1995).

9. John A. C. Hetherington \& Michael P. Dooley, Illiquidity and Exploitation: A Proposed Statutory Solution to the Remaining Close Corporation Problem, 63 VA. L. REV. 1, 2 (1977). For a classic judicial expression of the same intuition, see Donahue v. Rodd, 328 N.E.2d 505, 512 (Mass. 1975).

10. UNIF. PARTNERSHIP ACr $\S 31(2)$ (1914). While the dissolution may be wrongful, it will nonetheless be effective, and will immediately trigger a winding up of partnership affairs with the pro rata distribution of net proceeds. The Revised Uniform Partnership Act ("RUPA"), which is in effect in some states, has tried to limit the potential damage to going concems caused by this power, but individual partners retain much of their power to dissociate from the partnership and, by doing so, to trigger a buyout regime without triggering dissolution of the partnership itself. Thus, under $\S \S 601$ and 602 of the RUPA, a partner may dissociate from the partnership at will, at any time, rightly or wrongly. REVISED UNIF. ARTNERSHIP ACr $\S \S 601,602$ (1997). Under $\S 602$ (a), partners have the power to withdraw at any time, a power that is immutable under $\S 103(\mathrm{~b})(6)$. See id. at $\S \S$ 
proposed solution is legislation that provides shareholders of close corporations with the same exit option that partners classically possess.

Indeed, it is their intuition that lies at the heart of the evolution of minority shareholders' remedies for "oppression." Although the law has not gone as far as they had proposed, it has moved in that direction-driven, at least in significant measure, by an acceptance of their core claim of equivalence. Courts have been more willing to order dissolution and buyouts when convinced that the majority has engaged in oppressive conduct, and have also been more willing to find oppressive conduct when the minority's reasonable expectations have been violated.

The literature has also explored the conditions under which oppression-that is, opportunistic behavior-is likely to occur. This literature also provides support for buyouts and other remedies for minority oppression. ${ }^{11}$

Taking a different approach, Frank Easterbrook and Daniel Fischel have provided an alternative agency cost argument. ${ }^{12}$ They argue that the small number of shareholders and the overlap of managers and shareholders naturally aligns the interests of the two. This occurs for a variety of reasons. First, because managers are typically the residual claimants, actions taken by them will directly affect the value of their investment. The alignment is strengthened when shareholders have a large percentage of their wealth tied up in the venture. Furthermore, because the shareholders cannot easily alienate their holdings, they will be focused on maximizing the return. Second, participants in close corporations often have familial or other personal relations. The bond between them constrains conflict of interests. The result of the close alignment and the familial bond is that close corporations can have very low agency costs.

In the Easterbrook and Fischel view, companies choose the close corporate form to maximize the return on their low agency costs. If they wanted to, the companies could have either adopted the partnership model, contracted for shareholder agreements, or adopted specific protections for minority shareholders in the articles of incorporation. Consequently, those who choose the corporate form without modification should be assumed to prize stability of operations. The implications of their approach to the minority oppression debate are clear. Providing ease of dissolution or buyouts would only serve to weaken the bonds that align the parties' interests. Consequently, controlling shareholders in close corporations should be held to the same fiduciary standards as directors in publicly traded corporations, and no additional protections should be accorded to minority shareholders. ${ }^{13}$

602(a), 103(b)(6), $601 \mathrm{cmt}$. 2. Under $\S 701$, if a partner is dissociated from the partnership, and the partnership continues, the partnership must buy out the dissociated parmer's interest for "the amount that would have been distributable to the dissociating partner ... if, on the date of dissociation, the assets of the partnership were sold at a price equal to the greater of the liquidation value or the value based on a sale of the entire business as a going concern," less any damages caused by wrongful dissolution. Id. at $\S 701$.

11. Examples are Robert Thompson, The Shareholder's Cause of Action for Oppression, 48 BUS. LAW. 699 (1993) and Paul Mahoney, Trust and Opportunism in Close Corporations, in CONCENTRATED CORPORATE OWNERSHIP (Randall Morck ed., forthcoming 2000).

12. See EASTERBROOK \& FiSCHEL, supra note 6, at 228-252.

13. Easterbrook and Fischel, on one side, and Hetherington and Dooley, on the other, have provided for a grand debate which has engaged not only the academic literature, but also courts faced with allegations of minority oppression. For example, to Easterbrook and Fischel, minority oppression is no more likely in the 
But is the Heatherington and Dooley intuition correct? Are close corporations nothing more than "incorporated partnerships?" Do close corporations better serve the interests of the participants when exit is easy? Are Easterbrook and Fischel correct that the primary virtue of the close corporation is that it reduces agency costs and that no additional protection should be accorded minority shareholders? In order to answer these questions, we must open the lens wider to place close corporations in a broader context. With a wider lens, we can see that any explanation for the close corporate form has to be able to explain the second type of close corporation: the Silicon Valley start-up.

\section{B. Our Position and the Silicon Valley Start-Up}

In Silicon Valley, close corporations are started when the entrepreneur has an idea for a new product or service, such as a network switch. In the initial stage, the venture attempts to develop the new product. Whether the product will be successful is unknowable because its precise form and potential revenue streams have not yet taken shape. At this stage, the company will have relatively few shareholder/managers who supply the ideas, the initial capital for the venture, or both.

In the early stages of developing this new switch, the venture is highly dependent on these individuals for either the critical ideas or the financial capital. In addition, it is these individuals who believe in the high potential value of the network switch. Their investments of human and financial capital are made with the expectation that the payoff to the investment could be huge if the development stage idea can be implemented. But if the project were to falter, the value of these development stage investments would be nil. During this period, outsiders are unlikely to attach a similarly high value to the potential payoff to the concept. In this sense, the investments in our hypothetical are matchinvestments and the assets being created are match assets: they have great value to insiders and little value to outsiders. ${ }^{14} \mathrm{~A}$ defining characteristic of the Silicon Valley start-up is that its key assets are specific to the match.

The intensity of match assets creates a second important characteristic of close corporations. Between the time of the initial investments in research, development, and marketing, and the time at which the world can see if the switch will be a commercial success, it will be difficult to convince outsiders to invest in the project. Second stage venture capitalists may be interested in the venture, but given the still unproven value of the concept, will need to be brought in as insiders. To outside investors, the high cost of learning and staying informed about the switch's potential value makes them unwilling bidders at a price that values the match assets at the insiders' valuation. As a consequence, the company will be capital constrained with no easy access to outside financing at an appropriate valuation of the assets.

close than in the public corporation and should not be a cause of action with distinctive standards and remedies. See EASTERBROOK \& FISCHEL, supra note 6, at 231.

14. Investments in match are defined as investments that are more valuable to the contracting parties than to a third party. We use the term "match-specific" investment in this article in place of the more common "firmspecific" training for several reasons. First, the term "match-specific" investment captures the broader range of activities that create a good partnership, including training and learning-by-doing, but also including adaptations to each other's styles of interaction. In addition, the term is more general and does not restrain the investments to take place inside of a firm. Finally, the term match-specific leads one to identify the specific asset created or improved by the parties' investments. 
If any of the company insiders could trigger dissolution of the enterprise midstream, the forced sale of the match assets would result in substantial losses to the participants. Either the insider with the deepest pocket would buy the assets or the assets would be sold at a low price equal to the outsiders' bid price. If critical insiders could credibly threaten dissolution, they could use the threat to extract a greater share of the value of the enterprise. The resulting potential for opportunism would interfere with inducing optimal investment. ${ }^{15}$ The problem is akin to making an omelet: between the time the eggs are broken and the omelet sets, the cook knows his grand plan for the omelet, but to outsiders, the half-cooked omelet is unappetizing. Forced sales of half-developed switches and uncooked omelets go poorly.

In our approach, low agency costs are a natural result of the choice of form, but not the reason for adopting it. The close corporation will always have lower agency costs than an otherwise identical publicly owned company as a consequence of the small number of shareholders and the overlap of shareholders and managers. But agency costs do not explain why any given firm would adopt the close corporation form. The important exception, noted by Easterbrook and Fischel, is the family business. ${ }^{16}$ In a family business, low agency costs preexist in the familial relationship and the parties can thus capitalize on it by adopting the close corporation form. ${ }^{17}$ However, the Silicon Valley start-up is different. These shareholder/managers are unlikely to have preexisting familial ties and hence are unlikely to bring low agency costs to the formation of the close corporation. For at least the Silicon Valley start-up, the explanation for the choice of form is an operational factor: the need to lock-in parties while developing vulnerable match-specific assets. Reduced agency costs'are the result rather than the cause.

The problem of match-specific investments in a context with substantial asymmetry of information characterizes many other centrally important economic relationships. The employment relationship in which an employee with match-specific training is more productive than an employee hired from the external labor market provides a classic example. That employment relationship provides a critical foundation for our analysis precisely because most or all of the shareholders of close corporations are also employees.

Focusing on match assets also shows the fundamental differences between classical partnerships and close corporations. The dissolution at will feature of classical partnerships means that the form will best fit enterprises in which there are few if any assets that are not easily sold to third parties. In such cases, the benefits of dissolution at will are clear: by providing an easy exit, it prevents opportunistic rent-seeking. And the costs are minimal: when there are no sunk costs, when the principal assets are easily divided or sold, dissolution at will causes little harm. Thus, for a small law firm in which partners have their own clients, but wish to share office space, staff, and occasionally to refer business to other lawyers in the office with greater expertise or receive referrals, the

15. We define "rent-seeking," or, more generally, "opportunism," to be the expenditure of resources or efforts by one party in order to transfer resources from the other party to itself. This investment by the rentpayers wastes the joint profits of the parties because it creates no new wealth. Moreover, rent-seeking by one party typically causes the prospective rent-payer to expend resources in order to protect its share of the joint investment.

16. EASTERBROOK \& FISCHEL, supra note 6, at 229-30.

17. Id. 
partmership form is optimal. If the firm breaks up one day, very little value is trapped. Indeed, as one would predict, small law partnerships dissolve and reorganize constantly.

If participants can trigger dissolution at will, they will be unwilling, ex ante, to make investments in match for fear that, ex post, they will be held up. Because of this problem, when there are high investments in match, such as the Silicon Valley start-up, the costs of a rule of easy dissolution are huge. The traditional close corporation manifests the same features, although in a less highly articulated form. As in the Silicon Valley start-up, at the early stage of a new venture, the product or service will have no revenue but high costs. Similarly, once the initial investments of human and physical capital are made, the participants are locked in. In one respect, the traditional family business close corporation poses an even more difficult problem of protecting match investments. Unlike the Silicon Valley start-up, the traditional close corporation often expects to remain privately held indefinitely: the nature of the products or services are often such that selling to a third party is never a live option. However, traditional close corporations come in many forms and, at least in their formative years, many often hope to develop a product or service that may eventually be successful enough to be saleable to a third party.

Easy dissolution would also make it even more difficult to raise equity or debt capital than it already is. If the firm were required to retire the capital of an existing owner who sought to cash out, the cash constrained close corporation would be forced to raise new capital in a potentially unfavorable climate. Indeed, the shareholder dissension that characterizes a "minority oppression" case is likely to be highly correlated with negative events in the firm. A legal rule favoring easy exit threatens to shift the engine for raising new money into reverse, forcing capital to be retired under unfavorable conditions.

Similarly, the lock-in of the corporate form is important to creditors. In a setting of limited liability, creditors cannot be repaid from the individual wealth of the owners of a bankrupt company. In return, and in distinction to the rules of partnership, they are protected by the existence of an entity that is difficult to dissolve by the current owners. It is only with this protection that the squabbles among those who manage the company will be of limited interest to the creditors. Nowhere is this more important than in the close corporation, whose assets are difficult to value and whose current realizable market value - at forced sale-may be considerably below its future value. In such a setting, easy dissolution or buyout increases the risk of bankruptcy, thereby reducing the creditworthiness of the company. The traditional judicial reluctance to order dissolution or a buyout of minority shareholders lowers the credit risk of close corporations and allows them to borrow at more favorable terms.

Clearly, not all close corporations will be marked by heavy investments in match. Parties can, and do, choose alternative corporate and non-corporate forms based on very different motivations. In addition, parties sometimes make mistakes in their choice of form. In this regard, the analysis can be interpreted as defining the paradigm close corporation that is best served by the legal rules. Choose the close corporation form when heavy investments in match make restrictions on exit valuable. Choose the partnership form when exit is not costly and the parties can be given free reign to withdraw from the match. 


\section{LEGAL SETTING}

In this section, we describe the legal and nonlegal features of the close corporation. In so doing, we show how minority oppression arises and how it is constrained. This begins to set the stage for providing an answer to how the three cases noted at the outset should be resolved.

\section{A. Core Solution: The Corporate Form}

The standard, off-the-rack, corporate form provides a robust solution to the problem caused by threats of opportunistic exit. The standard form has several relevant terms. Directors are elected by a plurality of the shares. ${ }^{18}$ Dissolution requires a board resolution and a vote of the majority of the shares. ${ }^{19}$ Individual shareholders have no general right to sell their shares back to the firm.

The lock-in of the close corporation is created by the interaction of these terms with the absence of a public market for the shares. But the lock-in only affects the minority shareholder [Minor]. The majority shareholder [Major] can dissolve the corporation through a board resolution and a vote of a majority of the shares. The individual minority shareholders have no power to trigger dissolution. Minor likewise has no right to be bought out because, under the standard corporation laws, no shareholder has a general right to be bought out. If Major dissolves the corporation, Minor will receive a pro rata share if and when the firm is dissolved. ${ }^{20}$ In the meantime, Minor has a very limited right to be bought out by the firm--namely, the right to judicial appraisal upon a merger and, sometimes, a sale of all or substantially all of the assets. ${ }^{21}$

In addition to the lock-in provided by the statutory form, there are additional core properties of the form provided by a combination of statute and case law. The single most important combination is the prohibition on non pro rata distributions during the life of the firm combined with the close scrutiny of self-dealing transactions that attempt to evade this prohibition. The restrictions on non pro rata distributions are quite clear, and derive from several sources. A majority shareholder may not pay itself dividends without also paying the same per share dividend to the minority shareholders. ${ }^{22}$ It would be clearly illegal - and easily challenged - if the majority shareholder paid itself $\$ 1$ per share in dividends, while only paying minority shareholders $\$ .10$ per share.

Indirect means of distribution are also constrained. For example, if the majority shareholder attempts to divert assets by entering into a contract with the firm on preferential terms, the contract is subject to close judicial scrutiny. In addition, the majority shareholder bears the burden of establishing that the transaction is "entirely fair"

18. See, e.g., DEL. CODE ANN. tit. 8, § 216 (1974).

19. See, e.g., id. $\$ 275$.

20. See, e.g., id. $\$ 281(\mathrm{a})(4)$.

21. See, e.g., id. § 262(a); REVISED MODEL BUS. CORP. ACT $\S 13.02$

22. Del. CODE ANN. tit. 8, $\$ 170$ (1998); REvised MODEL BuS. CORP. ACT $\S 6.40$. The interpretation of these two sections is that, by definition, a dividend is a pro rata distribution. EDWARD P. WELCH \& ANDREW J. TUREZyN, Folk ON DELAWARE CORPORATION LAW: FundamEnTals $\S 170.2$, at 340-41 (Little Brown ed. 1993). 
to the corporation, where "entirely fair" is, when possible, defined by an arm's length market comparison. Compensation agreements are subject to a similar, but somewhat less exacting rule. ${ }^{23}$ Generally, to avoid the "entire fairness" scrutiny, compensation agreements must be authorized in advance by disinterested directors or disinterested shareholders, and even then, these are subject to scrutiny by the court under a "waste" standard. Similarly, attempts by the majority shareholder to take opportunities that belong to the corporation, or to use corporate assets for its own benefit, are limited (again imperfectly) by the "corporate opportunity" and related doctrines. ${ }^{24}$

While no one believes that these rules eliminate non pro rata benefits of control, most corporate law scholars agree that they significantly limit the magnitude of such diversions. As Cliff Holderness and Dennis Sheehan's empirical investigation suggests, legal restraints are surprisingly effective and probably the primary protection for minority shareholders. ${ }^{25}$ By limiting non pro rata distributions, these provisions go a long way to making the relationship incentive compatible. So long as the majority shareholders cannot prefer themselves in distributions, minority shareholders can depend on the majority to protect its interests.

The provisions addressing end-game scenarios are a second set of equally important standard protections that facilitate and protect the beneficial lock-in. When, for example, the majority shareholder triggers dissolution in order to take its capital out of the enterprise, the minority shareholders share pro rata in the net proceeds. ${ }^{26}$ Similarly, if the firm merges with another firm, shareholders receive equal shares and minority shareholders have a right to be bought out at "fair value," whether the firm survives or disappears. ${ }^{27}$ Under section 13.02 of the Revised Model Business Corporation Act (RMBCA), minority shareholders are also entitled to appraisal if the firm sells all or substantially all of its assets. ${ }^{28}$

Attempts by Major to circumvent these rules are constrained. If, for example, Major engineers a "squeeze-out merger" to rid itself of minority shareholders, Minor will be entitled to a judicial valuation of its shares, often with favorable procedural protections. Under Delaware law, Minor will be entitled to appraisal. ${ }^{29}$ In addition, Minor may also be entitled to bring a breach of fiduciary duty action. ${ }^{30}$ In evaluating such a squeeze-out merger, the Delaware court will place the burden on Major to prove the entire fairness of the price. ${ }^{31}$

23. ALI, supra note $1, \S 5.03$

24. ALI, supra note $1, \S \S 5.10-5.14$

25. Clifford G. Holdemess \& Dennis P. Sheehan, Constraints on Large Block Shareholders, in CONCENTRATED CORPORATE OWNERSHIP (Randall Morck ed., forthcoming 1999).

26. See, e.g., DEL. CODE ANN. tit. 8, §§ 275, 281 (1998); REviSEd MOdEL BUS. CORP. ACT $\S \S 14.02-$ 14.05 .

27. See Del. Code ANN. tit. 8, $\S \S 251,262$ (1998); Revised Model Bus. CoRP. ACt $\S 11.01-11.06$, $13.01-13.02$.

28. REvisEd MODEL BUS. CORP. ACT $\S 3.02$.

29. DEL. CODE ANN. tit. 8, $§ 262$.

30. See generally Weinberger v. UOP, Inc., 457 A.2d 701 (Del. 1983).

31. See Kahn v. Tremont Corp., 694 A.2d 422, 433 (Del. 1997). 


\section{B. Majority Opportunism and the Remedy for "Minority Oppression"}

But the very provisions that protect against opportunistic exit create the problem of opportunistic lock-in. Consider Case A, above. ${ }^{32}$ When Major has a falling-out with Minor, and Minor is left holding a minority interest in a firm controlled by Major, the standard corporation codes do not give Minor any right to be bought out, nor any right to dissolve the corporation. As a result, Minor may find itself locked into an investment that pays no dividends, in which Major makes all the decisions, and from which the only exit is to sell to Major at Major's bid price.

The core protection against majority oppression is the prohibition on non pro rata distributions and the related prohibitions on self-dealing, discussed above. The doctrine of "minority oppression" can be understood as a supplemental judicial response to this problem. Over the last twenty-five years, in response to the perceived plight of the locked-in minority shareholder, courts and legislatures have modified the law to provide remedies to minority shareholders that are not available to shareholders of publicly held corporations. ${ }^{33}$ This has been done in a variety of ways. First, legislatures in many states have broadened the circumstances in which minority shareholders may force the judicial dissolution of a corporation. In addition, legislatures have expanded the range of remedies beyond dissolution; namely, to include judicially mandated buybacks at a "fair price." 34 In most jurisdictions, shareholders can petition for dissolution on the grounds of illegality, fraud, misapplication of assets, or waste. ${ }^{35}$ "Oppressive conduct" by the majority shareholder is often listed as a basis for dissolution. ${ }^{36}$ Similarly, frustration of a "shareholder's reasonable expectations" is often a ground for dissolution. ${ }^{37}$ In other jurisdictions, shareholders' "reasonable expectations" are the measure of whether or not the majority shareholder has oppressed the minority. Second, judges have become more willing to order dissolution or a buyout, particularly if they are convinced that majority shareholders have engaged in "oppressive conduct" or that shareholders' "reasonable expectations" have been violated. Third, courts have made it easier, substantively and procedurally, for minority shareholders to bring suit against majority shareholders for breach of fiduciary duties.

Minority shareholders have benefited from several trends. First, courts have tended to make the fiduciary duty owed by majority shareholders stricter. Second, courts have

32. See supra Part I.

33. In the following extremely cursory summary, we follow the excellent treatment provided by Robert Thompson, supra note 11. For further details, see Robert B. Thompson, Corporate Dissolution and Shareholders' Reasonable Expectations, 66 WASH. U. L.Q. 193 (1988). For even more details, see F. HODGE O'Neal \& Robert Thompson, Close Corporations: Law AND Practice (3d ed. 1986 \& Supp. 1995); F. Hodge O'Neal \& Robert B. ThOMPSON, O'Neal's Close Corporations (3d ed. 1991); F. Hodge O'Neal \& ROBERT B. THOMPSON, O’NEAL'S OPPRESSION OF MiNORITY SHAREHOldERS (2d ed. 1985).

34. Thompson, supra note 11 , at 718-22.

35. Id. at 708 .

36. See, e.g., REviSED MODEL Bus. CORP. ACT $\S 14.30(2)$ (ii) ("The [court] may dissove [sic] a corporation ... in a proceeding by a shareholder if it is established that . . the directors or those in control of the corporation have acted, are acting, or will act in a manner that is illegal, oppressive, or fraudulent."). Under REVISED MODEL BUS. CORP. ACT $§ 14.34(\mathrm{a})$, when shares are closely held, "the corporation may elect, or, if it fails to elect, one or more shareholders may elect to purchase all shares owned by the petitioning shareholder at the fair value of the shares."

37. Thompson, Corporate Dissolution, supra note 33, at 199. 
shown an increased skepticism towards whether the majority has fulfilled its duties. Finally, courts have broadened the situations in which a minority shareholder can bring a (procedurally simple) direct suit in place of a (procedurally complex) derivative suit. Together, these developments have moved close corporation law towards partnership law, both with regard to the ease of dissolution as well as with regard to the duties owed by one shareholder towards the others.

These various doctrines have proved difficult to contract out of. ${ }^{38}$ Because the doctrines find their foundations in either a contractual "covenant of good faith" or a fiduciary duty, and because contracts waiving such duties are typically void, a straightforward contractual opt-out will not be effective. Similarly, contractual attempts to divest.courts of authority to dissolve the corporation are generally void. Ironically, while the overwhelming trend in close corporation law has been to permit tailoring of the standard terms by contract, the area of minority protection has stood out as an exception.

In summary, a cause of action has evolved for "shareholder oppression" or, perhaps more accurately, as Robert Thompson suggests, for "shareholders" dissension." 39 This cause of action has increased the ability of shareholders of the close corporation to turn to a third party decision-maker for relief from what shareholders argue is oppression or unfair conduct by the controlling shareholders. Although the cause of action is still evolving and its boundaries remain obscure, these developments have increased the bargaining power of the minority, ex post, vís a vís the majority.

The critical question is whether such developments are likely to benefit the participants in close corporations. The close corporation is the ideal form for enterprises with a high density of match assets because of, and not despite, its lock-in feature. Accordingly, the development of shareholder oppression law may interfere with the efficiency of the close corporation form. To reduce this possibility, what principles should guide its evolution?

\section{When a Legal Solution?}

The possibility of opportunistic behavior does not itself provide a sufficient basis for judicial or legal intervention. While the problem of opportunism is pervasive in relationships characterized by investments in match and asymmetry of information, such problems are only sometimes solved by legal intervention. To put it somewhat differently, the issue is when does a non-legally enforceable, norm-governed relationship serve the parties' interests better than a third party, law-governed relationship?

From this perspective, one cannot understand the role of legal intervention in the close corporation until one first understands the extent to which the relationship is already self-govemed by non-legally enforceable norms enabled by the core legal form. We proceed in several steps. First, because many minority oppression cases are employment-related and the employment relationship is the best example of a relationship with match investments and asymmetrical information that is almost entirely norm-govemed, we start with a brief summary of that analysis. Second, we apply that mode of analysis to the close corporation, examining the analogous non-legally

38. Dale A. Oesterle, Subcurrents in LLC Statutes: Limiting the Discretion of State Courts to Restructure the Internal Affairs of Small Business, 66 U. COLO. L. REV. 881, 888 (1995).

39. Thompson, supra note 11 , at 708 . 
enforceable structures that constrain opportunistic behavior. Third, we examine the fundamental legal protections that make that self-govemment possible. With that groundwork laid, we turn to the appropriate judicial role in rooting out residual opportunism.

\section{CONSTRAINTS ON OPPORTUNISM}

\section{A. The Employment Relationship and Investments in Match}

The employment relationship, and particularly the relationship between managers and the firm, is often characterized by large investments in match. ${ }^{40}$ These include employee investments identifying the employer, in understanding and improving job performance, and in learning the organizational and operating structures of the company and its core competencies. The company in turn invests in identifying and training the employee in the above factors and in the monitoring of the employee's performance to determine the most profitable future path of joint match-investments. Many of these investments are match-specific and would be lost if the employee left the company.

Given the magnitude of the sunk investments in match, the threshold question is why the parties enter an ongoing relationship without adopting (legally enforceable) contract terms to protect their interests. The explanation is twofold. First, the costs of contracting over the multitude of interactions would be extremely high in a relationship that is continuous and evolving. Second, self-enforcing, but not legally enforceable, norms emerge to constrain opportunistic behavior.

The widespread but puzzling features of the employment relationship can be best understood as a remarkably robust set of self-enforcing employee protections. Consider, for example, why firms choose to discharge an employee for inferior performance rather than adopting a less severe penalty, such as reduction in wages. While this may initially seem to be in conflict with the presumed interest of the parties in maintaining the employment relationship, asymmetric information requires termination rather than a wage reduction. Because of asymmetric information, employees know their work effort, but firms do not. Firms can learn by monitoring, but constant monitoring is very costly. To save on costs, workers are infrequently monitored. The harsh penalty is driven by the low detection rate. If most shirking goes undetected, workers must be penalized an amount greater than the expected loss of any specific incident.

However, this optimal deterrence explanation does not explain why the penalty for inferior performance cannot be a large salary reduction. The answer is that if the firm could simply declare that an employee was underperforming and cut his or her salary, the employer would have an incentive to overstate underperformance, thereby reducing costs and increasing profits. Channeling the employer's response into discharge is thus incentive-compatible. In declaring inferior performance, the company must accept the loss of the employee. The company is willing to do this if the employee's performance is indeed inferior, but not otherwise. The practice of laying off workers during a slowdown, rather than reducing wages, can be understood in a similar fashion.

40. For a fuller analysis, see Edward B. Rock \& Michael L. Wachter, The Enforceability of Norms and the Employment Relationship, 144 U. PA. L. REV. 1913 (1996), and more generally, Michael L. Wachter \& Randall D. Wright, The Economics of Internal Labor Markets, in THE ECONOMICS OF HUMAN RESOURCE MANAGEMENT 86, 89 (Daniel J.B. Mitchell \& Mahmood A. Zaidi eds., 1990). 
From this perspective, the legal doctrine of employment at will-the doctrine according to which companies can discharge employees for good reasons, bad reasons, or no reasons at all - is best understood as a rule of judicial non-intervention, and not the incorporation of a substantive term of the employment relationship. ${ }^{41}$ Even the critics of the rule do not claim that companies often discharge workers for bad reasons or no reasons. When the substantive norm that governs the employment relationship seems to be "no discharge without cause," why would the parties prefer a legal rule that says "no intervention?" The answer follows from the preceding analysis.

An enforceable contract must be specified ex ante in terms that can be verified ex post by the third-party enforcer. In the employment context of continuous and evolving interactions, such a contract would invariably be incomplete. Consequently, the expectations of the parties would be difficult to establish at any given time. Since much of the information is asymmetrically available to one party, many of the outcomes cannot be verified by third parties.

In this context, legal enforcement of the norm of "no discharge without cause" would undermine the norm-based system because of the difficulties of ex post third-party verification. As a starting point, proving just cause would require that the employer engage in additional detection costs, which reduces the value of the match. In addition, the third party would have to learn enough about the internal norms of the firm to determine whether a violation of the norm was meaningful enough to constitute "cause." Moreover, the presence of investments in match increases the likelihood of error when third parties enforce the norms, because the valuations of those assets depend not on market prices but on the parties' own valuations. From the employer's perspective, just cause exists when the continuation of the match with the particular employee has negative net present value, including the reputational cost of taking too tough or too easy a stance in the face of the perceived violation.

Self-enforcing norms better serve the parties' interests. On the one hand, they allow the party with the detailed information to act on his or her knowledge at low cost. At the same time, they protect the uninformed party by forcing the informed party's actions into channels that make opportunistic behavior unprofitable.

In cases where norms are insufficient to deter opportunistic behavior, other nonlegal remedies are available. The parties are involved in repetitive interactions, and the employer is also a repeat player in the competitive external labor markets. Both make it costly for an employer to act opportunistically. In the ongoing employment relationship, bad play by the employer generates retributive bad play by the employees, whether in concert or individually. This can take the form of hard-to-detect work slowdowns, badmouthing the employer in the public domain, or even covert vandalism and theft. Such actions cause direct losses to the employer and force an increase in monitoring which is also costly. In the labor market for new employees, a reputation for bad play is similarly costly in the form of increased difficulty in attracting or retaining the best employees. Finally, in the case of non-supervisory employees, unionization is an effective alternative, forcing the relationship into the domain of explicit contracting with a collective bargaining agreement.

41. For a fuller analysis, see Rock \& Wachter, supra note 40. 
Given these advantages, the resilience of the employment at will doctrine in the employment relationship is unsurprising. Whenever courts encroach on the doctrine through a theory of contractual interpretation, one finds that the parties, to the extent permitted, contract around the interpretation by specifying, for example, that the terms of the employment handbook are not to be taken as legally binding. The best explanation for this resilience is that, in a relationship characterized by match investments and asymmetry of information, the parties are best served by self-enforcing rather than thirdparty enforced agreements. It is not that opportunistic behavior is eliminated entirely, only that the benefits of the flexible norm-govemed relationship outweigh the costs of residual opportunism.

We now turn to the analogous problem in the closely held corporation.

\section{B. Close Corporation: Non-Legal Constraints on Opportunism}

As in the employment context, many of the persistent features of the close corporation provide substantial, albeit non-legally enforceable, protection against opportunities for abuse that are opened up by the form itself. In this subsection, we explore how these non-legal constraints operate, and show that the seemingly detrimental lock-in of the close corporation, supplemented by the prohibition on direct and indirect non pro rata distributions, renders the form largely incentive-compatible. By locking in Major, and prohibiting non pro rata payments, Major, in seeking to maximize the value of his stake in the firm, likewise will maximize Minor's stake.

This is particularly true in the case when the close corporation is like an unfinished omelet. Like the shareholders' individual inability to trigger dissolution, the lack of a market prevents exit or opportunistic threats of exit, except under narrowly defined circumstances. Locked in together, the parties can count on each other's dedication to cooking the omelet properly. This issue is also handled, at least in the Silicon Valley start-up, by legally enforceable contracts that protect early investors through particular financing structures. ${ }^{42}$ In general then, the close corporation forces the investor into a high degree of illiquidity, an unfavorable state from a traditional investment perspective, but an illiquidity that serves the interests of the parties by locking up participants in the enterprise.

A variety of other features of the close corporation can be understood as supplementing and complementing this structure. The overlap between suppliers of capital and labor reduces information asymmetries and transaction costs. Whether in the traditional or Silicon Valley variety, the overlap puts all the relevant players into continuing contact, providing both the entrepreneur and the capital suppliers with continuing information on their own and on the company's performance.

The result is that the operations of the close corporation are akin to the stylized employment relationship discussed above. The same types of self-enforcing norms are operational. In both cases, the participants are engaged in repetitive interactions where the parties can sanction each other for bad play, and can apply the appropriate sanctions more reliably than third parties who cannot observe and monitor the behavior of the

42. See Sahlman, supra note 8 , at $489-503$ (outlining the contract and analyzing the relationship between external investors and the venture capital firm); Gompers, supra note 8, at 1464 (discussing the contracting costs incurred by venture capitalists). 
parties. In the close corporation, the ability of the participants to identify improper behavior will be much greater than the ability of any third party. Moreover, the ability of the participants to punish bad behavior will likewise be great. The disenchanted minority shareholder/manager armed with greater access to company performance information has more leverage to sanction bad play by the employer than does the individual manager in a public corporation.

Indeed, if anything, the results found in the employment relationship are stronger in the case of the close corporation because of Easterbrook and Fischel's point on agency costs. ${ }^{43}$ The most difficult problem in the employment relationship is aligning the interests of the employees with the company. Pay for performance, particularly stock options for senior executives, reduces the misalignment in the public company; however, the device is both imperfect and costly to the shareholders. In the close corporation, pay for performance is a natural result of the fact that employees are also shareholders. More generally, in the public corporation's employment relationship, senior executives and shareholders occupy mostly independent spheres. In the close corporation, the spheres overlap. The wide govemance mandate of its board of directors results from the overlap of roles between capital and labor providers. The shareholder/employee is involved in the governance issues normally reserved for shareholders in the publicly-held corporation and for employees in the employment relationship.

The robustness of the norm protection is illustrated by the high-tech sector. The occasions for opportunistic renegotiation that arise from sequential performance are a particular problem in high-tech start-ups. Venture capitalists (VC) worry that the entrepreneurs, after accepting early financing from the $\mathrm{VC}$, will find other financing once the idea proves its worth, or will quit and go to work elsewhere after the VC has invested millions of dollars. Entrepreneurs worry that the venture capitalists will find other managers once the idea has been committed to paper and has proven its worth. These concerns, which are simply a special and detailed case of the more general problems of the close corporation, are the subject of intense contracting and research. We will illustrate by considering a few details.

The VCs protect themselves in several ways. ${ }^{44}$ First, a surprising stylized fact of the Silicon Valley start-up is that the VCs have the right to replace the entrepreneur with a professional manager. ${ }^{45}$ In addition, the terminated entrepreneur often can be forced to sell his stock back to the firm at cost—well below its actual value. Finally, entrepreneurs do not automatically receive generous severance packages.

Thomas Hellmann explains why the venture capitalists would demand such terms as a response to a hold-up problem. ${ }^{46}$ Entrepreneurs gain private benefits of control, which lead them to stay on longer than they should. By contrast, the VCs' incentives are much better aligned with maximizing firm value, and, moreover, they are better situated to identify better professional managers. In Hellmann's model, unless the VC receives the

43. See supra note 12 , and accompanying text.

44. For further discussion of the provisions in this paragraph, see Barry et al., supra note 8, at 461-63; Gompers, supra note 8; Gorman \& Sahlman, supra note 8; Lemer, Venture Capitalists and the Oversight of Private Firms, supra note 8; and FENN ET AL., supra note 8, at 32-33.

45. Thomas Hellmann, The Allocation of Control Rights in Venture Capital Contracts, 29 RAND J. ECON. 57, 58 (1998).

46. Id. at 60 . 
right to displace the entrepreneur, it will not invest optimally in searching for replacement managers.

How the entrepreneurs protect themselves is equally interesting. After all, if the VC has the right to terminate the entrepreneur, which triggers a stock buyback at cost, there would seem to be an incentive to do so. The entrepreneur's protections here are entirely non-legal, but they are substantial. Most importantly, VCs are repeat players in the startup business and are likely to be constrained on a number of fronts. First, they compete to provide financing for the most promising start-ups and are thus likely to be constrained by reputational effects in their aim to maintain their position in relation to other start-up companies. In addition, the VC has to replace the entrepreneur with another person. Wrongful discharge of the chief executive officer, even if protected from judicial second guessing by the employment at will doctrine, is not a strong starting point in any recruitment process. Finally, the discharge will raise questions with other capital suppliers. It is a negative signal under the best of circumstances and is likely to raise the company's cost of capital. Of course, this is precisely the story we earlier told about employment at will more generally, and the fact that employment at will governs even in a domain of such intensive contracting as the Silicon Valley high-tech sector is further support for our analysis.

That still leaves open the question of why the entrepreneur's stock position can be bought out at cost. The likely answer here, as stressed throughout the paper, is the difficulty of determining market value for a start-up company that does not trade in a public market. The contract term that sets the buyback price at cost, however, is a default setting. Again, the VC will have a strong reputational incentive to deal fairly with the discharged entrepreneur, including paying a higher price if one can be reliably determined.

Another feature that is particularly striking is the absence of any general right to trigger dissolution or to be bought out at a pro rata share of firm value. The choice made in the high-tech sector, where contracting is most explicit, is to leave the lock-in in place and to avoid judicial valuation of hard-to-value assets, even at the cost of some residual opportunism. This is consistent with the more general reactions to the special close corporation chapters of corporation codes, promulgated by some jurisdictions in response to developments in the law and academic commentary. However, few firms avail themselves of the opportunity to organize under such statutes. On the contrary, close corporations seem to stubbornly adhere to organizing under the general corporation codes.

\section{The Proper Judicial Role in the Three Cases}

We have argued that the lock-in effect of the corporate form is what makes it so attractive for firms that benefit from extensive investments in match. We have argued further that there is a variety of structural features that limit the incentives and constrain the ability of the participants to act opportunistically-the principal threat to optimal match investment. In addition, the law limits significantly the non pro rata distribution of assets from the corporation and provides for pro rata treatment upon dissolution and merger. Moreover, the law provides for a judicial valuation of minority shares in a 
sharply limited number of situations. Finally, partictpants are free to contract for additional or different terms, an opportunity which participants liberally use.

The remaining question is what room, if any, is there for further judicial intervention on behalf of minority shareholders? The concem is that judicial attempts to protect minority shareholders against opportunistic behavior will jeopardize the web of features and protections that makes the close corporation form so attractive and popular for firms with substantial match-specific assets. ${ }^{47}$ In guarding further against the potential for minority oppression, do we end up increasing the potential for opportunism in the relationship by providing Minor with more chances to act opportunistically against Major?

\section{A. Case A: Employment at Will as Minority Oppression?}

Consider Case A, ${ }^{48}$ in which Major fires Minor. Minor, the terminated minority shareholder, invested in match-specific assets related to a new network switch, with the expectation that he would share in the returns generated from the venture. We are concerned that Minor will not be able to share the fruit of his efforts now that he has had a falling-out with fellow shareholder Major. Moreover, having lost his job, we are also concermed that Minor will be forced by both economic necessity and the absence of a liquid market for shares to sell his shares at a fraction of the pro rata value of the firm. The Minors of the world, never certain whether they will end up on the wrong end of a disagreement, will not invest optimally in match-specific assets unless their employment and investment expectations are protected.

There are two variations of Case A that must be considered. First, assume that Major is the entrepreneur who supplies the ideas and has $60 \%$ of the stock, while Minor supplies the money and owns $40 \%$. What possibilities for opportunism arise in the absence of any special protections for minority shareholders? Suppose that, after Minor has invested his money and the idea is developing well, Major says "I want an additional $10 \%$ of the equity or else you will never see a dime of profit," or any number of variants that amount to the same idea. Is this a credible threat? Clearly the answer is no. First, because of the restrictions on non pro rata distributions, if Minor does not get any dividends, neither will Major. Second, if Minor is providing more than money (management advice, industry contacts, etc.), then Major may still need him. Third, the market and the need for a stream of additional capital will constrain Major's ability to threaten Minor. In these circumstances, Minor will be unwilling to put more capital into the business. Moreover, other potential investors are also likely to refuse when they learn of the incident. As long as Minor remains a material owner of the company, or is known in the financial community, those in the financial community who are considering investments will undoubtedly leam of Major's opportunism. Empirical research on the high-tech sector

47. A weaker proposal would be to make the minority protection a default setting, from which firms could opt out. The experience of states that have special optional close corporation provisions suggests that there would be boilerplate opt-out option provisions from default settings. The widespread contracting around departures from the employment at will doctrine through the interpretation of employee handbooks likewise suggests that any variation must be mandatory to be effective.

48. See supra Part I. 
confirms that the financial individuals are quite good at contracting for particular devices that protect against this sort of opportunism. ${ }^{49}$

Now consider the reverse scenario. Major supplies the financial resources and holds $60 \%$, while Minor is the entrepreneur who supplies the ideas and possesses $40 \%$. Once Minor commits his idea to patentable paper, Major fires Minor. Minor has neither an employment agreement nor any shareholders' agreement that provides for a buyout right. Does Minor have a claim on our sympathies?

In this case, a threshold question is whether Minor's contribution is "one off." If it is, then Minor opens himself up to opportunistic renegotiation if Minor commits the contribution before Major finishes performing. However, when the contribution really is "one off," without the necessity for ongoing involvement (the scenario that gives rise to the threat of opportunism), there is an easy transactional solution: a license or sale. The individual (or individuals) who discovers something important, but has nothing further to contribute, should license or sell the idea to Major, who will then develop it. Similarly, when the capital provider has only a single investment to make and has nothing else to contribute, he should buy limited partnership shares with a VC who can then control the opportunistic Majors because of their superior knowledge and network. Of course, the one-time, would-be financier may purchase the patent or license it, only to go broke due to his own lack of good follow-up ideas. The critical fact, however, is the following: when the contribution is indeed "one-off," no business reason exists to use the corporate form.

Focus, then, on the difficult cases that will involve plaintiffs who believe they are still making contributions to the firm. If brought before a third party for resolution, Major will provide one of two explanations--either that Minor was fired because Minor has been shirking, or that Minor is not suited to the current demands of his job or needs of the firm. In other words, Major will allege that Minor is no longer making valuable contributions. Minor will maintain that he was fired because Major wanted to take Minor's ideas for himself and capture all of the gains.

This is precisely the same problem that is addressed in employment law by the employment at will doctrine. In this case, sorting out the truth raises the precise difficulties of relying on a third party to resolve employment disputes. It is very difficult for the court to determine ex post what the parties' reasonable expectations were ex ante. Even if the court could determine the parties' expectations, performance is largely unobservable; therefore, the court will be unable to determine whether the expectations have been satisfied. As in the employment context, Major and Minor know much more about who is telling the truth than a judge could ever discover. In addition, valuing the relationship of specific assets to determine if opportunism has occurred and, if so, to set damages, is, in theory and in practice, necessarily speculative. Finally, permitting Minor to sue for "oppression" or breach of "reasonable expectations" will, as in the employment context, undermine the web of self-enforcing relationships that provides the principal protection for investments in match.

Against this background, consider the classic Case A case, Wilkes $v$. Springside Nursing Home, Inc. ${ }^{50}$ Wilkes, along with three others, established a nursing home, with

49. See, e.g., Gompers, supra note 8.

50. 353 N.E.2d 657 (Mass. 1976). 
the work and profits apportioned more or less equally. ${ }^{51}$ After a falling-out, the others forced Wilkes out of active participation in the management of the enterprise and cut off all corporate payments. ${ }^{52}$ Wilkes alleged that his termination constituted a breach of the fiduciary duties owed to him by the majority shareholders. ${ }^{53}$ According to the court, "The severance of Wilkes from the payroll resulted not from misconduct or neglect of duties, but because of the personal desire of [the other shareholders] to prevent him from continuing to receive money from the corporation." 54 In holding for Wilkes, the court stated:

A guaranty of employment with the corporation may have been one of the 'basic reason[s] why a minority owner has invested capital in the firm.' The minority stockholder typically depends on his salary as the principal return on his investment, since the 'eamings of a close corporation . . . are distributed in major part in salaries, bonuses and retirement benefits.' Other noneconomic interests of the minority stockholder are likewise injuriously af fected by barring him from corporate office. Such action severely restricts his participation in the management of the enterprise, and he is relegated to enjoying those benefits incident to his status as a stockholder. In sum, by terminating a minority shareholder's employment or by severing him from a position as an of ficer or director, the majority effectively frustrate the minority stockholder's purposes in entering on the corporate venture and also deny him an equal return on his investment. 55

The court then recognized the extent to which the controlling group needed "room to maneuver in establishing the business policy of the corporation." 56 As a compromise, the court established a "legitimate business purpose" test: "When an asserted business purpose for their action is advanced by the majority, . . . we think it is open to minority stockholders to demonstrate that the same legitimate objective could have been achieved though an alternative course of action less harmful to the minority's interest." 57 Because the majority had not shown a legitimate business purpose in terminating Wilkes' involvement in the firm, the court held for Wilkes.

In addition, there is a second argument suggested which raises some additional issues. The court notes that "Other noneconomic interests of the minority stockholder are likewise injuriously affected by barring him from corporate office. Such action severely restricts his participation in the management of the enterprise, and he is relegated to enjoying those benefits incident to his status as a stockholder." 58 The exact thrust of the court's argument here is somewhat unclear. One reading of this claim is that there are valuable, non-economic benefits that come with participation in the firm. To the extent that this is the argument, it simply amplifies the no-just-cause claim.

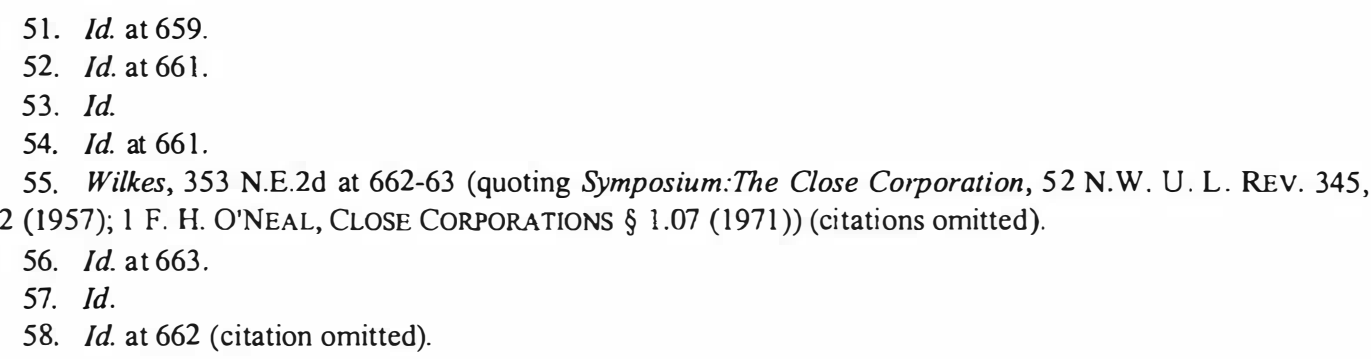


However, there is a much more relevant alternative reading-namely, that terminating Wilkes' participation in the firm made it impossible for him to continue to monitor his co-shareholders, and because of the asymmetry of information that characterizes the close corporation form, this rendered his continued participation as a shareholder untenable. This is an argument that differs both from the faulty employment at will concerns as well as from the non pro rata distribution concerns that will be discussed below, and will be addressed in subpart C, below. 59

Could the other shareholders in Wilkes have been behaving opportunistically? Could they have terminated Wilkes' relationship with the firm in order to expropriate his investment, considering that he had already committed whatever special skills and knowledge he possessed? Absolutely. Opportunistic behavior is clearly possible in such circumstances. Yet that alone is not sufficient to justify the court's response, which was namely a case-by-case analysis of terminations to determine if the firm acted with a "legitimate business purpose" and with no "less harmful altematives." 60 That is the same as stating that because opportunistic behavior is possible in the employment relationship, a court should scrutinize each termination to see if it was for just cause. ${ }^{61}$

Case A and Wilkes both present situations in which the majority shareholder(s) could have been behaving opportunistically. However, in both cases, there are numerous non-legal constraints on such behavior. If Major treats Minor badly, Major will have greater difficulty convincing current shareholder/employees to continue investing time, money, and effort in the enterprise, as well as convincing prospective investors or prospective employees to join the firm on the same terms that Minor did. These are the reputation and self-help stories described earlier.

Suppose that Minor's idea or Plaintiff Wilkes' stake is so valuable that Major is willing to suffer whatever reputational cost will be incurred by acting badly? Minor and Wilkes are still not unprotected. If Major successfully markets, develops, or sells Minor's patent, or if Springside Nursing Homes sells the nursing home to a national chain, Minor and Wilkes are still protected by the rule of no non pro rata distributions. If Major ultimately decides to liquidate or sell the firm in order to take its profits on Minor's invention, Minor will likewise receive its share. In the meantime, Minor will be in a position to make Major's life difficult by making requests for information and threats of litigation. Finally, if these protections are insufficient and the problem is significant, future Minors always have the option of specifying additional protections by contract.

On the other side of the equation, permitting judicial scrutiny of Minor's or Wilkes' termination is in effect to undermine the very advantages of the informal, non-legally enforceable set of protections that constitute relational "contracts." As we have argued elsewhere in connection with the employment at will doctrine, the attempt to root out residual opportunism-opportunism that slips through the network of legal and non-legal constraints-threatens to undermine the self-enforcing character of the overall relationship. ${ }^{62}$ Moreover, as we will discuss in more detail below, the court's difficulty in determining whether a discharge was for a "legitimate business purpose" is aggravated by

59. See infra notes 80-85 and accompanying text.

60. Wilkes, 353 N.E.2d at 663.

61. This, of course, is precisely the argument that opponents of the employment at will doctrine make.

62. See Rock \& Wachter, supra note 40 . 
the difficulty of valuing match assets in awarding Minor the "fair value" of his shares in a judicially mandated buyout.

The Wilkes case is a good example of the difficulties courts have with the employment issues that frequently overlay close corporation cases. ${ }^{63}$ For example, was the court correct in saying that there was no legitimate business purpose in terminating Wilkes' employment? On the one hand, we are told that there was no misconduct and that Wilkes "had always accomplished his assigned share of the duties competently." 64 The court, however, made no attempt to determine whether Wilkes' services were still needed. Apparently he was not replaced, suggesting overstaffing. By not appreciating the norms of the employment relation, the court stumbled badly, inferring a right to continued employment, subject only to proof of misconduct. Such a right is so far at variance with employment practice anywhere that its insertion in the case undermines the logical application of the legitimate business purpose standard.

\section{B. Case B: Stock Buybacks as Minority Oppression?}

Consider Case B: Major forces the firm to buy back a portion of Major's shares (while leaving Major in control) at an entirely fair price, without giving Minor a proportionally equal opportunity to cash out. The principal variant of Case B is one in which the Major Group, the controlling shareholder group, buys back the shares of one of the control groups without giving Minor a proportionally equal opportunity to cash out. In either case, does Minor have a claim on our sympathies? In this instance, we are concerned that Major, even if its transaction with the firm meets the "entire fairness" valuation standard, receives a benefit that Minor does not - the ability to cash out a portion of his holdings, when doing so is profitable. We are also concerned that the ability for Major to "have his cake and eat it too" will undermine Minor's incentive to invest optimally in the firm by breaking the beneficial lock-in feature of the corporate form.

This is the issue in Donahue v. Rodd Electrotype. ${ }^{65}$ In Donahue, the controlling shareholder, Dad, distributed most of his shares to his children who worked in the business. Subsequently, his sons wished that Dad would retire, but he would only do so if he could sell some of his remaining shares back to the firm (with the remainder distributed later to his sons). ${ }^{66}$ The firm bought back Dad's shares without offering an equal opportunity to the minority shareholders, who challenged the buyback as a breach of fiduciary duty. ${ }^{67}$ After a lengthy discussion of the extent to which close corporations are really little more than incorporated partnerships, a discussion which is not only wrong but unnecessary to the decision of the case, the Supreme Judicial Court of Massachusetts held that "if the stockholder whose shares were purchased was a member of the controlling group, the controlling stockholders must cause the corporation to offer each

63. The importance of employment disputes and the employment at will doctrine in the close corporation setting is stressed generally in Johnston, supra note 6 .

64. Wilkes, 353 N.E. $2 \mathrm{~d}$ at 664.

65. 328 N.E.2d 505 (Mass. 1975).

66. Id. at 510 .

67. Id. at 511 
stockholder an equal opportunity to sell a ratable number of his shares to the corporation at an identical price." 68

Nixon v. Blackwell likewise involved a stock repurchase plan. ${ }^{69}$ In Nixon, the firm established an ESOP plan that held company stock and provided departing shareholder/employees the right to receive cash for their interest in the ESOP plan when they retired. ${ }^{70}$ In addition, the company established key-man insurance policies that allowed proceeds from the plan to be used to purchase stock in executives' estates. ${ }^{71}$ The nonemployee minority shareholders objected on the grounds that they were not provided an equal opportunity to sell their shares. ${ }^{72}$ The Chancery Court held that it was "inherently unfair" for the controlling shareholders to provide liquidity for themselves without providing comparable liquidity for the non-employee shareholders. ${ }^{73}$ The Delaware Supreme Court reversed, holding that the stock repurchase plans served a legitimate corporate interest by maintaining an overlap between employment and ownership and that the defendants met the "entire fairness" standard. ${ }^{74}$

Plaintiffs claimed that the preferential repurchase of shares was a breach of fiduciary duty. The claim raises the question of the extent to which preferential repurchase schemes are problematic, not solely because the price is too high (a version of pure self-dealing), but because they undermine the alignment of interests between the majority and minority shareholders that makes the firm work. There are two aspects to the claim here. First, as described in more detail below, to the extent that a high density of match assets characterizes close corporations, it becomes very difficult for the court to determine whether the repurchase price was entirely fair, because there is no market benchmark. ${ }^{75}$ Second, even if one could value the shares, the preferential repurchase can be objectionable because it undermines the incentive-compatible lock-in that is the great attraction of the legal form. These aspects of the problem lie at the heart of both Nixon and Donahue, and are not explicitly discussed in either decision. These are very different situations than those that occurred in Case A, because they do not raise the intra-firm employment questions that made the prior case so difficult.

These cases also differ from the classic non pro rata distribution of firm assets. Here, the firm receives something of value in return for cash-shares of the firm. Normally, under the duty of loyalty, transactions between a fiduciary and the firm are not per se void or voidable. Rather, they are judged under the entire faimess standard and, if entirely fair, are valid.

The question is whether regulating such transactions is necessary to supplement the prohibition on non pro rata distributions, and, if so, how to do so. The dimensions of the problems, and the tradeoffs among different approaches, are complex. First, one needs to maintain the beneficial lock-in of participants that harmesses the self-interested efforts of the controlling shareholders in the interests of all participants. Second, one must prevent

68. Id. at 518 (footnote omitted).

69. 626 A.2d 1366 (Del. 1993).

70. Id. at 1371 .

71. Id. at 1371-72.

72. Id. at 1373.

73. Blackwell v. Nixon, No. CIV.A.9041, 1991 WL 194725, at *5 (Del. Ch. 1991).

74. Nixon, 626 A.2d at 1377.

75. See infra Part V.C. 
non pro rata distributions which can be made by the advantageous purchase or sale of shares. Third, one needs to maintain flexibility in the management of the firm's capital structure and compensation practices. Finally, one needs to provide for the orderly exit of participants.

Three types of cases must be accounted for. First, the control group may decide to buy out a minority shareholder. In such cases, there is little potential for opportunism. Second, the control group may decide to buy out a shareholder/employee who is exiting, or who has exited, the firm, as in both Donahue and Nixon. Here, the potential for opportunism is greater. The control shareholders may prefer one of their own over outside nonemployee shareholders, and there may be disguised self-dealing. On the other hand, as continuing shareholders/employees, they will also bear a pro rata share of the cost. Finally, the controlling shareholder sells shares to the firm without releasing control. This is the most dangerous circumstance-the controlling shareholder has a clear incentive to receive an excessively high price, while not giving up any of the private benefits of control. 76

How does the law handle this range of cases? One reading of the law is to generalize Donahue into a general prohibition on the selective buyback of shares in close corporations - that is, an equal opportunity rule. This rule largely eliminates the opportunistic use of buybacks, but at the cost of impairing the firm's flexibility in adjusting its capital structure, compensation policies, and providing exit to shareholders. A second possibility is to generalize Nixon into a general standard permitting selective stock repurchases whenever they are "entirely fair." This preserves the firm's flexibility in compensation and in providing exit, but at the cost of diluting the beneficial lock-in. A final plausible possibility is that both Donahue and Nixon were correctly decided within their individual domains. Nixon addressed one aspect of the more complicated middle cases. Note that the Delaware Supreme Court's ruling in Nixon emphasized that the buyback was pursuant to a long-standing corporate policy to which the minority apparently did not object when first instituted, and that the company adopted the policy to benefit the corporation. Indeed, the court viewed the policy as a form of deferred compensation that provided the firm with flexibility to adopt standard deferred compensation packages which were used in other firms to encourage superior employee performance. Moreover, the court emphasized how the policy was applied in an entirely nondiscriminatory fashion among retiring employees. In contrast, the Delaware Chancery Court viewed the policy not as a deferred compensation practice, but as a straight financial structure issue which granted members of the control group preference over non-employee shareholders in cashing out.

As in case A, courts must be careful not to confuse employment relationship issues with straightforward capital structure questions. If courts prevent firms from adopting deferred compensation plans because of an equal opportunity rule on the exit end, close corporations will not be able to develop optimal incentive-based compensation

76. A related issue is presented by Kahn v. Tremont Corp., 694 A.2d 422 (Del. 1997). In that case, Harold Simmons was the controlling shareholder of Valhi Corp., which owned NL Industries. Simmons was alleged to have used his control over a third corporation, Tremont, to cause Tremont to buy Valhi-owned shares of NL Industries at an excessively high price. Simmons was able to reduce his holdings in NL Industries without giving up control, at an allegedly excessive price, without other shareholders having an equal opportunity to cash out. 
mechanisms. In evaluating such cases, courts must look to both the compensation and the financial capital aspects of the situation, with particular attention to indicia of selfdealing.

Because of the potential for self-dealing when a control group buys out one of its own, the entire fairness rule applies. Under the entire faimess rule, the Delaware courts look at both "fair dealing" and "fair price." According to the Delaware Supreme Court, fair dealing was established by the fact that the company adopted stock purchase plans for legitimate corporate purposes (maintaining the overlap between ownership and control) and provided plans to the shareholders/employees on a nondiscriminatory basis. Interestingly, the issue of whether the price paid for the shares was excessive did not arise.

In the close corporation context, both fair price and fair dealing can be problematic. Whether a repurchase plan is discriminatory depends on how the relevant group is defined. In Nixon, the Chancery Court found the plan discriminatory because it did not treat employee and non-employee shareholders equally. ${ }^{77}$ Although the Delaware Supreme Court could have found the situation non-discriminatory because it treated all employee shareholders equally, it ultimately held that the discrimination against nonemployee shareholders was justifiable. ${ }^{78}$ Similarly, relying on fair price is problematic when, as we discuss in more detail elsewhere, the valuation problem is often intractable.

How, then, can one understand Donahue and its relation to Nixon? The primary difference between the two cases is that the control group in Donahue was a family group. One may worry that the payment to Dad is disguised self-dealing, that the more Dad gets for his shares the less the children who work in the business will have to contribute to buy him an apartment in Miami. The very family relations that Easterbrook and Fischel emphasize as important in reducing agency costs within the close corporation significantly increase the potential for self-dealing when the family group is dealing with nonfamily shareholders. ${ }^{79}$

If the existence of a family relationship significantly increases the risks of selfdealing, then one can understand Donahue as consistent with Nixon. Reading them together, the standard in both cases is entire faimess, a standard not met in Donahue because of a (conclusive) presumption that the repurchase was not entirely fair. One can also understand the role of equal opportunity here. If adopted by the control group, it is powerful evidence that the transaction is entirely fair. In cases like Donahue, offering minority shareholders an equal opportunity to exit reverses the presumption that buying back Dad's shares redounds to the sons' individual benefit by relieving them of some other financial obligation.

Appreciate, for a moment, the subtlety of the structure. While the firm is developing or producing omelets, and therefore has a reputational stake in not breaching its agreements, there are a variety of structural features which align interests, and the principal legal restriction is no non pro rata distributions. In other words, the majority shareholder can refuse to pay dividends, but only at the cost of all of the shareholders'

77. Blackwell, 1991 WL 194725, at *6.

78. Nixon, 626 A.2d at 1379.

79. EASTERBROOK \& FISCHEL, supra note 6, at 231. 
capital remaining trapped in the firm. This lock-in, plus the other features outlined above, provides a strong incentive for the majority shareholder to maximize firm value, thereby protecting the minority shareholders' investments as well.

But the lock-in is not absolute. As reconstructed above, the law has evolved to permit sufficient flexibility to allow the firm selectively to offer some shareholders the opportunity to cash out without offering the same opportunity to all shareholders, when doing so benefits the firm. In doing so, the law distinguishes according to the potential for opportunistic behavior by controlling shareholders. Thus, when the firm buys shares from non-controlling shareholders, the business judgement rule applies. When it buys shares from members of the control group who are exiting, the entire fairness standard applies, with "equal opportunity" being powerful evidence of entire fairness. Finally, when the firm buys back shares from a controlling shareholder or shareholding family who is remaining in the firm, the potential for self-dealing is so great that entire fairness is not satisfied absent equal opportunity.

Once, however, the company enters the last period — defined by the distribution of a firm's equity capital-the norm against non pro rata distributions again protects locked-in minority shareholders. The rule of no non pro rata distribution means that minority shareholders are able to cash out at the pro rata valuation. Major, as the majority owner, gets to define when the omelet is finished and signals that fact by voiding the lock-in, either by dissolution, merger, or an initial public of fering of stock. But, now, Minor gets to exit, either through a pro rata share of the firm equity in dissolution, or through an appraisal proceeding if the firm is merged into another firm, or by selling out to the market after a public of fering of shares.

The rule against non pro rata distributions is the lynch pin-it is the rule that prevents the participants from jumping out of these channels. So long as non pro rata distributions are controlled, remaining problems that arise between shareholders can be handled by analogy to employment at will, where courts should not intervene in the absence of an explicit contract.

The analysis, then, largely parallels the employment at will account. In both cases, locking participants into a relationship in which there are substantial investments in match is valuable because it avoids the hold-up problem (i.e., threatening to leave before the omelet is done). It also forces the parties to resolve the problems themselves, avoiding defections; provides high-powered incentives to succeed; and prevents the parties from threatening to impose heavy costs (by threatening expensive litigation) as a way of renegotiating the division of the joint surplus.

In this sense, the principles applied in cases A and B are the same. In Case A, Minor wants to be cashed out, at least if he cannot continue as an employee. In Case B, Major wants to be cashed out, at least if he can continue in control. On our analysis, the answer is the same in both cases: neither can cash out without the other shareholders cashing out to the same degree. And, in both cases, the reason is the same: the omelet may not be finished yet. Major gets to decide when the omelet is finished, but once Major declares the omelet finished, Minor shares pro rata. Meanwhile, neither gets to pull out equity.

\section{The Courts' Comparative Advantage: Do Cases A and B Differ?}

Our analysis sharply distinguishes between Cases A and B. But, say some, our distinction misses the point of what the courts are doing in these cases, and in particular, 
why it is important for courts to intervene in Case A situations. ${ }^{80}$ The problem, they say, is that courts cannot distinguish between market rates of compensation and excessive compensation, and therefore should and do protect minority shareholders' employment in the firm as a second best technique for protecting their investment expectations. On this view, unless you protect the expectation in employment, including the expected salary, the financial investment in the firm becomes worthless. That is, if pro rata distributions are to be defended, Case A must be treated like Case B in the sense of judicial intervention to protect the minority shareholder.

But this argument misses the fundamental reason that courts should not and generally do not intervene in employment cases. The argument incorrectly assumes that a court is better at distinguishing discharge for cause from "minority oppression," and when the remedy is a buyout, calculating "fair value," than it is in figuring out whether payments by the firm to the majority shareholder constitute a non pro rata distribution to a shareholder. In fact, because of the presence of significant investments in match, exactly the opposite is the case, and the court is likely to be far better at policing non pro rata distributions than employment issues.

Compare the two inquiries. In Case A, the court must first determine whether a termination was for cause or, more or less equivalently, for a legitimate business purpose. Having determined that a termination was unjustified, the court must then either order reinstatement or, more likely given the bad blood between participants, either order dissolution of the corporation or a buyout of the minority shareholder at fair value. In either case, the court will have to calculate the value of the firm because, given the presence of substantial investments in match, the highest valuing buyer in a dissolution will most likely be the majority shareholder.

The first inquiry faces all of the problems that have been discussed with regard to the employment at will doctrine. Not only is the for-cause/fair-value standard a much harder standard to apply, it does not even eliminate the need to police non pro rata distributions. Even if an employee shareholder has been discharged for cause, so long as he is a shareholder, his financial investment in the firm must still be protected against such distributions by the majority.

The second inquiry is even worse. If we are correct that the close corporation form is most appropriate for firms with substantial investments in match, the valuation problem will be intractable. A market valuation will be unavailable (because the assets are worth much less to third parties than to the participants in the enterprise), and a cash flow analysis will face all of the informational problems that make it impossible to sell the assets to third parties.

Generally, a company's assets are valued by first estimating the future discounted stream of the free cash flow that they generate, and then attaching a multiple that reflects the discount rate and the risk associated with the cash flow. The estimate of free cash flow is based on several factors, including the past performance of the company in generating revenue, the performance of comparable assets in other companies, and the market outlook for the products produced by the assets. This standard valuation methodology, while adequate for established firms, does not work well in most close corporations because the required data is not available. The company may have very

80. We owe the acute articulation of this point to the comments of Robert Thompson. 
limited past performance, the management may be too untested to allow reliable future predictions, and the company's products or services may be too novel to allow easy comparisons with seasoned firms. It requires time to determine whether the product ideas will work out and produce free cash flow of any given size.

Indeed, the difficulties of valuing the assets of the close corporation are, at least in the Silicon Valley context, an important explanation for why the company continues to be privately held. By the time enough information is available on likely performance to value the match assets of the close corporation, it is time for the close corporation to go public. Similarly for firms furthest from access to a public market, the valuation problems are the greatest. Take, for example, the classic mom and pop corporation. When mom and pop are the enterprise, it is difficult to distinguish any ongoing market value from the value provided by the principals. The enterprise's match assets may be so tied to mom and pop that no independent valuation can be attributed to the firm's other assets. Moreover, in this case, generating additional years of performance data will not bring the firm closer to a reliable market valuation. Valuing the firm by looking at the sale value of comparable firms would also be stymied by the distinctiveness of the enterprise and the difficulty in identifying comparables. Finally, when comparable companies can be found, one's confidence in the resulting valuations will be challenged by the thinness of the market.

By contrast, consider the judicial inquiry under the norm of no non pro rata distributions in Case B. First, insofar as the claim is one of a failure to pay dividends, the inquiry is straightforward: as long as no one is receiving dividends and the earmings are retained in the corporation, the court can defer to the discretion of the board, knowing that everyone's eamings are equally locked in. Second, consider the manifold varieties of basic self-dealing, ranging from excessive salaries to non pro rata dividends, to diversion of corporate opportunities to sales to or purchases from the corporation. This is the classic domain of the duty of loyalty. The basic principle here is that the majority shareholder will bear the burden of establishing entire faimess, where entire fairness is defined with reference to an unconflicted arms' length transaction.

Consider salaries as an example, although the analysis applies equally to other transactions with the corporation. The standard is a market standard: are the controlling shareholders receiving more than the market wage? When, as is often the case, the controlling shareholders set their own salary, standard corporate law analysis imposes the burden of establishing entire faimess on the controlling shareholders-that is, showing that the wage is at or below the comparable market level. While plaintiffs typically fail in challenges to dividend policy or employment policy, they apparently fare substantially better in challenges to excessive compensation. ${ }^{81}$

Moreover, courts have already had experience in determining, in the tax context, whether close corporation salaries are excessive. ${ }^{82}$ When there were tax advantages to paying dividends as above market salary, the IRS scrutinized such payments on precisely

81. Donahue v. Rodd Electrotype, 328 N.E.2d 505, 514 n.15 (Mass. 1975) (“Attacks on allegedly excessive salaries voted for officers and directors fare better in the courts.... What is 'reasonable compensation' is a question of fact... The proof which establishes an excess over such 'reasonable compensation' appears easier than the proof which would establish bad faith or plain abuse of discretion."); see also Alaska Plastics v. Coppock, 621 P.2d 270 (Alaska 1980); Crosby v. Beam, 548 N.E.2d 217 (Ohio 1989).

82. See, e.g., Alaska Plastics, 621 P.2d 270. 
this basis. As the tax preference for distributions in salary disappears, determining whether a salary meets the market test is likely to be easier, because relevant benchmarks will be less distorted. ${ }^{83}$

In addition, the courts have at their disposal their traditional methods of shaping the decisional process by allocating burdens of proof. Thus, the courts will be more deferential to salaries that are set by independent outside directors than by the majority shareholders themselves. For example, the problem of diversion of profits to majority shareholders through excessive salaries seems nonexistent in the Silicon Valley high-tech context, in part at least because managers' salaries are set by, or at least in consultation with, the venture capitalists.

While judicial intervention in Case A forces courts to value the firm with the associated problems created by the high density of match-specific assets, no such difficulties bedevil Case B. In the salary context, the question is whether a salary is excessive relative to market equivalents. In the context of other transactions with the firm, the issue is likewise whether the terms of the transaction between the majority shareholder and the firm meet the market test. In the case of dividends, the question is only whether all shareholders receive the same amount.

Indeed, the only times the court must enter the thicket of valuing the firm are when the firm is being sold (by a merger or a sale of assets, in some jurisdictions), when the minority shareholders request appraisal, and when there is a selective stock repurchase. In the case of an arm's length merger, the shareholders have the opportunity to receive the same consideration as the majority shareholder, but believe that their shares are worth more. But, in those circumstances, precisely because the firm is being sold, there is at least one measure of valuation available. Moreover, because all shareholders share equally in the proceeds of a sale or dissolution, the majority shareholder is likely to represent the interests of the minority shareholders. Major is unlikely to sell the firm unless it has reached the stage where its third party value is beginning to approach the value to the participants. ${ }^{84}$ As discussed earlier, selective stock repurchases present genuinely difficult issues.

The focus on preventing non pro rata distributions points the way towards incremental modifications within the existing framework to increase the level of enforcement without entering the thickets of "for cause," without disturbing the employment at will standard, and without judicial valuation. For example, once it is clear that the issue is preventing non pro rata distributions, the courts should make it easier to challenge contracts between the controlling shareholder and the firm. Consider Crosby v. Beam, 85 in which the majority shareholders entered into self-dealing contracts with the

83. In this context, it is worth observing that changes in the tax law undermine the received wisdom that close corporations pay out all their earnings as salary, benefits, or pension payments to avoid double taxation of earnings (once at the corporate level and once at the shareholder level). With the advent of corporate forms and tax rules that permit "pass through" taxation, this avoidance strategy has lost much of its justification. Without double taxation, why pay out everything as salary?

84. A more difficult problem arises when it is the majority shareholder who is buying out the minority shares. Under these circumstances, the court has no choice but to enter the difficult problem of valuation, and, although it can and does seek to avoid the difficult valuation questions by encouraging the use of independent negotiating structures to mimic an arm's length sale, its success in doing so is only limited.

85. 548 N.E.2d 217 (Ohio 1989). 
firm, including unreasonable salaries, use of corporate property, life insurance, low interest loans, and so forth. ${ }^{86}$ The legal issue was whether the minority shareholders must challenge the agreements through a derivative suit, which is subject to the demand requirement and in which any recovery is paid into the corporate treasury, or whether the minority shareholders could bring a direct suit. ${ }^{87}$ The court, after a long discussion of how, in a close corporation, the majority shareholders owe fiduciary duties to the minority shareholders, held that the suit could be brought as a direct suit, with recovery going directly to the plaintiffs:

Given the foregoing, if we require a minority shareholder in a close corporation, who alleges that the majority shareholders breached their fiduciary duty to him, to institute an action pursuant to Civ. R. 23.1, then any recovery would accrue to the corporation and remain under the control of the very parties who are defendants in the litigation. Thus, a derivative remedy is not an effective remedy because the wrongdoers would be the principal beneficiaries of the recovery. 88

According to our analysis, the court got it half right. The fact that the majority is accused of engaging in a self-interested transaction with the firm is, of course, central and, in a derivative suit, would fully justify excusing demand as obviously futile and allowing the plaintiff to proceed directly to the merits of the action. But if the guiding principle is preserving the beneficial lock-in effect of corporate form against attempts at non pro rata distributions, then the correct result is that any excessive payments go back into the corporation where they remained locked up until the majority chooses to make some sort of pro rata distribution. This is an adjustment to the procedural requirement for derivative suits in light of the special nature of close corporations (or, perhaps, simply an application), but is a quite different sort of adjustment than that adopted by the Ohio Supreme Court.

Along the same lines, an appreciation of the central issue will lead courts to give less deference to the board of directors in setting its own compensation or in approving asset distributions of other sorts. Finally, it makes it clear that, in the absence of some independent decision-maker, the burden of proof falls on the majority shareholder to justify salaries and other payments as entirely fair.

\section{Case C: Is the Sale of Control for a Premium a Non Pro Rata Distribution?}

In the close corporation, we take the rule of no non pro rata distributions to have the status of a commandment. It is the principle that makes the whole thing work, which allows minority shareholders to rely on majority shareholders to manage the firm in the general shareholder interest. It is this principle that allows for optimal investment in match-specific assets. Finally, enforcing this principle frees the courts from having to enter into the impossible (and destructive) tasks of sorting out, on the one hand, whether a discharge of a minority shareholder/employee was for cause and, on the other hand, how much the firm is worth.

86. Id. at 218 .

87. Id. at 219.

88. Id. at 217 (citing F. Hodge O'Neal \& Robert B. ThOMPSON, O’NeAl's Close Corporations $\S$ 8.11 (3d ed. 1987)). 
What then does one make of Case $\mathrm{C}$, in which Major sells its majority block to a third party who is unwilling to buy the minority shares on equal terms? In the U.S., the general common law rule is that the majority shareholder may sell its holdings and a buyer may buy its holdings without offering the minority shareholders an opportunity to participate. ${ }^{89}$ The principal exception is when the majority or controlling shareholder has reason to believe that the buyer will loot the corporation. ${ }^{90}$ There are a few cases to the contrary, but this is the general rule. ${ }^{91}$ Much has been written on the efficiency of competing rules governing sales of control. We cannot enter that thicket here, but must address the relationship between sales of control and non pro rata distributions and, more generally, the connection between sales of control and firms with heavy match investments.

Case $\mathrm{C}$ seems to be an interesting and difficult mix of Cases $\mathrm{A}$ and $\mathrm{B}$. When the majority shareholder sells control, he thereby terminates his relationship with the firm, while taking a larger than pro rata share of firm value. On its face, the majority shareholder's sale might seem to violate the no non pro rata distribution norm, or, at the very least, the related norm governing end games. When a majority shareholder sells its block, it gets cash at a time when the other shareholders do not. Moreover, the minority cannot even check the impact of the sale on their share of the presale equity of the firm. Finally, unlike an arm's-length merger or dissolution in which the shareholders share on an equal basis, often with a right of appraisal, here the minority shareholders not only do not share, but also have no right to appraisal. In short, we worry that the majority shareholders will sell out the minority shareholders in the process of selling control. As before, we worry about this prospect to the extent that it undermines the minority shareholders' willingness to invest in match-specific assets, thereby reducing the parties' joint surplus.

Yet the situations also seem quite different. For example, the sale of a majority block differs from the non pro rata payment of dividends in several important respects. First, the sale of the blocks results in a change of control, while the various non pro rata distributions leave the incumbent controller in place. Second, the new controller steps into the shoes of the old controller with all of the same restrictions on non pro rata distributions, restrictions which, suggests the work of Holderness and Sheehan, may be surprisingly effective. ${ }^{92}$ Third, to sell a majority block, one needs to find a buyer. This imposes a barrier that is not present in non pro rata distributions.

At least in form, there is no difference between Major selling his shares to a new Major and any Minor selling its shares to a new Minor, except perhaps the amount received for the shares. There is, indeed, an active market for shares of closely held Silicon Valley start-ups, in which (sophisticated) minority shareholders sell their shares to other (sophisticated) investors pursuant to Rule 144A. ${ }^{93}$

Why might minority shareholders, ex ante, agree to permit the majority shareholder to sell its block without an equal opportunity rule, despite the extent to which the sale

89. See, e.g., Zetlin v. Hanson Holdings, Inc., 397 N.E.2d 387 (N.Y. 1979).

90. See, e.g., ROBERT CLARK, CORPORATE LAW 478-98 (1986).

91. See generally Einer R. Elhauge, The Triggering Function of Sale of Control Doctrine, 59 U. CHI. L. REV. 1465 (1992).

92. Holdemess \& Sheehan, supra note 25.

93. Private Resales of Securities to Institutions, 17 C.F.R § 230.144A (1997). 
may be in tension with the beneficial lock-in and the principle of no non pro rata distributions? This old chestnut of corporate law looks somewhat different against the backdrop of our emphasis on match investments. Take again, as given, that the close corporation is characterized by a large percentage of match assets. Moreover, assume that the lock-in of the corporate form, with exit at the close of play, is part of what renders the form incentive compatible.

The principal concern with permitting sales of a majority block is that the buyer and seller may collude to impose additional costs on third parties-here, the minority shareholders. Absent third-party effects, one can trust the buyer and seller to figure out what is best for them. ${ }^{94}$ So long as the constraints on private benefits of control are reasonably binding, the likelihood of third-party effects is small and one can leave it to the buyer and seller of control to negotiate terms. ${ }^{95}$ In such cases, the seller will sell only if the buyer is better at managing the corporation than the seller, which will benefit the minority. Indeed, because of the difficulties in valuation, the buyer will likely have to be substantially better than the seller.

The key point in the close corporation context is that private benefits of control are restrained by a set of formal and informal sanctions. For example, suppose the trapped minority believes that the planned sale, through one mechanism or another, will itself diminish the value of its investment. One remedy is to sue for a breach of the duty of loyalty. Whether or not the minority wins, such suits raise a red flag for any diligent new person thinking of becoming a controller. The reaction of the potential buyer is now three-fold. First, he doubles the due-diligence concerning the information provided by the majority. Presumably the disgruntled, frozen-in person might even be helpful here in supplying information. Second, the potential entrant may think twice about buying into a close corporation where the minority is disgruntled. In some circumstances, this may lead the buyer to insist on buying $100 \%$ of the corporation. Third, the buyer may react by a standard "curse on both their houses" and choose to pull his bid entirely or to bargain hard to buy the controller's share at a cheap price. In brief, because of the fewness of numbers, the parties can hurl mud at each other with great effectiveness.

Another consideration figures in as well: the orderly exit of controllers. Sometimes the majority shareholder gets tired of being the majority shareholder, or knows that he has lost his effectiveness. Sometimes, also, the firm is not yet ready to be sold to a third party because the omelet is not yet cooked. How do you make sure that there is someone around to play the role of majority shareholder, with all its burdens and risks? The common law answer may be the legal equivalent to the informal rule in voluntary organizations that you cannot stop chairing a committee until you find a replacement.

94. One might also wony that the exiting controller is selling a lemon and the entering controller does not know that. But even if this occurs, the minority is no worse off-instead, it is just as badly off as before. Moreover, this should not be a likely event. Those who buy into an existing close corporation are, in general, likely to be a highly diligent group. Indeed, they are likely to be more careful than the controller who entered at the outset.

95. This is the core of Elhauge's channeling explanation for existing doctrine: the looting cases (highly liquid assets; big premium) identify those cases in which the likelihood of collusion between buyer and seller are highest; the free sale cases, by contrast, are situations in which it is difficult for buyer and seller to collude successfully, either because of the nature of the (illiquid) assets or for other reasons. See Elhauge, supra note 91. 
Because the omelet is not yet finished, it will be very difficult to convince a third party to take over the omelet business, and it is possible that the majority shareholder will have to take a substantial discount in order to induce a third party to take over. In such cases, the minority shareholders are beneficiaries, not because the buyer will have bribed the controller to leave, but because the controller has bribed the new controller to enter. ${ }^{96}$

If this is more or less right, then the incentive compatible rule in the close corporation context-so long as the prohibition on non pro rata distributions is reasonably well enforced-is the same as in the public corporation context; namely, that absent a shareholders' agreement to the contrary, any shareholder, majority or minority, is free to sell to whomever is willing to buy (except a looter). The buyer, majority or minority, steps into the shoes of the seller, and is locked in to the same extent.

This means that in the articulation of the pro rata principle, one must emphasize that it applies to distributions. On this view, the control on diversions of the cash flow does most of the work. Indeed, this may support Elhauge's argument that the laissez faire rule is most appropriate for those situations, or, more generally, those systems in which non pro rata distributions are sharply limited, while the equal opportunity rule may better fit those situations in which such distributions are badly controlled. ${ }^{97}$

\section{E. Minority Shareholders' Informational Rights}

In the earlier discussion, we discourage judicial intervention in Cases A and C. In both cases, however, there are potential problems with respect to the minority's access to company information which, if addressed, would strengthen our case. Recall the argument suggested in Wilkes: once Minor is terminated, the underlying asymmetry of information will make it untenable to continue as a minority shareholder. This is an important argument, as we have argued that the asymmetry of information associated with a high density of match-specific investments is part of what makes the close corporation form appropriate, and that the overlap between shareholders and managers helps manage that asymmetry of information.

On the one hand, it may be that this untenability is optimal for the parties under the circumstances. Both the high-tech sector and the traditional close-corporation sector show that mandatory provisions that provide for the buyback of employee shares upon termination of employment at either cost or book value (easily measured amounts that are often far below actual, pro rata value) are quite common.

But, as the Case B cases indicate, it is not always the case that it is untenable to be a minority nonemployee shareholder. Whether, and the extent to which, such a position may be tenable depends, in part, on the extent to which the courts police the norm of non pro rata distributions. This, in tur, depends on the extent to which courts provide for and enforce minority rights to information. Like the enforcement of the norm against non pro rata distributions, enforcing minority informational rights protects the beneficial

96. The difficulty of valuation may enter in another way. Because the omelet is only partly cooked, it would be extremely difficult for a court to determine whether the selling majority shareholder got too muchi.e., whether he was paid a "premium" for control. This may be the reason why courts focus on preventing non pro rata distributions, rather than on measuring the extent to which the majority shareholder was overpaid. But, of course, a rule preventing a majority shareholder from selling control for a premium need not involve judicial valuation: an equal opportunity rule would be as easily implemented here as it was in the Wilkes case.

97. Elhauge, supra note 91. 
characteristics of the close corporation form, without dragging the courts into either adjudicating employment at will issues or firm valuation.

To operate effectively, however, Minor must know when Major is acting opportunistically. Minor, as either a shareholder/employee or as only a shareholder, has the ability to impose or threaten Major with informal sanctions. When Minor is employed, he has all of the normal methods of sanction that apply to an employee. In his role as a shareholder in a closely held company, Minor also holds considerable power to impose sanctions. But if Minor is either discharged from the company or left employed, but in a nonmanagerial capacity, he is unlikely to leam the requisite information necessary to know when and how to act.

Minority shareholder information rights come from two sources: state law and federal law. Under state law, shareholders are entitled to substantial information. Delaware corporate law provides:

Any stockholder, in person or by attomey or other agent, shall, upon written demand under oath stating the purpose thereof, have the right during the usual hours for business to inspect for any proper purpose the corporation's stock ledger, a list of its stockholders, and its other books and records, and to make copies or extracts therefrom. A proper purpose shall mean a purpose reasonably related to such person's interest as a stockholder. 98

As interpreted, title 8, section 220 of the Delaware Code provides minority shareholders of the close corporation with substantial rights to information. First, "in the case of a close corporation, inspection rights will be liberally construed in favor of a minority stockholder." 99 Second, finding out the facts necessary to determine if Major is engaging in self-dealing, or mismanagement, are both clearly "proper purposes" under Section 220.100

The Federal securities laws provide the second principal source of informational rights for minority shareholders. Although close corporations are not subject to the periodic disclosure obligations, section 10(b) of the Securities Exchange Act and rule 10b-5 apply fully. ${ }^{101}$ Rule 10b-5 has proved most important in end-game scenarios. Minor, who is terminating his relationship with the firm, negotiates to sell his shares back to the firm or to the majority shareholder. At the same time, unbeknownst to Minor, Major is engaged in serious discussions with a potential acquirer of the firm, or with an

98. DEL. CODE ANN. tit. 8, $\S 220$ (b) (1998). Minority shareholders have similar informational rights under the RMBCA. REVISED MODEL BUS. CORP. ACT. §§ 16.01-16.04 (1997).

99. WELCH \& TUREZYN, supra note 22 , $\$ 220.6 .2$, at 466.

100. Id. (with citations). In addition, minority shareholders who are in litigation with the corporation have substantial rights to information under the civil discovery rules, whether in federal or state court.

101. Under rule $10 \mathrm{~b}-5$ :

It shall be unlawful for any person ... (a) To employ any device, scheme, or artifice to defraud, (b) To make any untrue statement of a material fact or to omit to state a material fact necessary in order to make the statements made, in the light of the circumstances under which they were made, not misleading, or (c) To engage in any act, practice, or course of business which operates or would operate as a fraud or deceit upon any person, in connection with the purchase or sale of any security.

17 C.F.R. $\$ 240.10$ b-5 (1997). On the applicability of 10b-5 to close corporations, even in the sale of the entire business, see Landreth Timber Co. v. Landreth, 471 U.S. 681 (1985). 
investment banker who wishes to take the firm public. Sometime after Minor sells his shares, the acquisition is announced, which places a value on the firm far in excess of what Minor received. Minor sues, alleging that, had he known of the merger discussions, he would not have sold his shares. In such circumstances the courts have held that, when Major is buying out Minor, Major has a duty to disclose all material nonpublic information, including negotiations to sell the firm or take it public. ${ }^{102}$

This structure fits well with our previous analysis. Like the vigorous enforcement of the norm against non pro rata distributions, so, too, the enforcement of these informational rights protects the incentive compatibility of the close corporation form. The state law rights to information help to alleviate (although clearly not eliminate) the underlying asymmetry of information while Minor is a shareholder. Major's duty under $10 \mathrm{~b}-5$ to disclose material facts or abstain from buying Minor's shares protects and reinforces the end-game norm: upon liquidation or merger, shareholders share equally. ${ }^{103}$

\section{CONCLUSION}

The close corporation form is ideally suited to enterprises in which there is a high density of match-specific assets. The limitations on exit, combined with the rule against non pro rata distributions, largely prevent opportunistic behavior by the majority shareholder towards the minority shareholder. By locking both into the enterprise, the majority shareholders, in maximizing their own wealth, will, to a large extent, also maximize the wealth of the minority. Indeed, many of the persistent features of close corporations can best be understood as self-enforcing mechanisms to protect the participants from misbehavior by fellow participants.

This is not to say that all enterprises that use the close corporation form make use of these attributes. An important conclusion of this paper is that by isolating the distinctive features of close corporations, we identify those enterprises that are best suited for the close corporation form. The enterprises that most value the lock-in are precisely those

102. See, e.g., Michaels v. Michaels, Michaels and Hyman-Michaels, 767 F.2d 1185, 1194-97 (7th Cir. 1985); Holmes v. Bateson, 583 F.2d 542, 558 (1st Cir. 1978); Rochez v. Rhoades, 527 F.2d 880, 887-88 (3d Cir. 1975); Thomas v. Duralite Co., 524 F.2d 577, 584 (3d Cir. 1975).

103. There is an additional set of issues that arise when Minor is subject to a mandatory buyback provision upon termination of his relationship with the corporation. The issue arises whether and when Major has a duty to disclose news that may be of significance to Minor in deciding whether to terminate his relationship with the firm. Jordan v. Duff \& Phelps, 815 F.2d 429, 440-41 (7th Cir. 1987); Smith v. Duff \& Phelps, 891 F.2d 1567, 1575 (11th Cir. 1990). A related issue is whether such a mandatory buyback provision should be read to displace the employment at will presumption in the employment relationship. The answer has been negative. See, e.g., Ingle v. Glamore Motor Sales, Inc., 73 N.Y.2d 183, 189 (N.Y. Ct. App. 1989) (mandatory buyback provision does not get shareholder/employee any protection against at will discharge). Indeed, in some cases, the buyback provisions explicitly provide that "nothing herein contained shall confer on the Employee any right to be continued in the employment of the Corporation." Jordan, 815 F.2d at 446 . Finally, the question also arises whether the firm can fire an employee simply in order to trigger the mandatory buyback provision. Gallagher v. Lambert, 549 N.E.2d 136, 138 (N.Y. 1989) (no breach of fiduciary duty to terminate minority shareholder triggering mandatory buyback, even if firing is motivated by desire to take advantage of lower valuation); Knudsen v. Northwest Airlines, 450 N.W.2d 131, 132 (Minn. 1990) (stock option agreement which expires when employee ceases to work for employer does not imply any covenant of good faith termination for cause). Compare the majority opinion of Justice Easterbrook in Jordan, 815 F.2d at 439, with Justice Posner's dissent, 815 F.2d at 446 . These issues, while fascinating, are beyond the scope of this article. 
Silicon Valley start-ups with new products that need time to set. The close corporation, in its best use, thus serves as an incubator for tomorrow's publicly owned corporations.

After examining the extent to which the enterprise form itself constrains opportunistic behavior by participants, we analyzed the classic problem(s) of minority oppression in the close corporation. As we understand it, minority oppression can best be understood as a combination of two separate and separable problems. The first aspect, captured in Case A, is a version of precisely the same problem that, in employment law, arises under the heading of employment at will: the situation in which Major terminates Minor's employment. Here we demonstrated that the law, by adopting the same passive stance as it does in the employment context, avoids threatening and undermining the selfenforcing structure in place.

The second aspect of the problem, captured in Case B, is fundamentally different from employment at will and involves attempts by Major to make non pro rata distributions of company assets. Here, we showed that vigorous judicial enforcement of a prohibition on such distributions, including the vigorous protection of ancillary rights to information, is necessary to enforce norms of non-opportunism. We further showed that courts are much better at sorting out issues of this sort than employment at will issues, because doing so does not require either relying on unverifiable factors, or valuing assets that the courts are unable to value.

Out of our appreciation of the beauty of the close corporation comes several conclusions. First, our analysis implies that the parties themselves, rather than the courts, are best able to resolve the nasty employment issues that animate many bitter close corporation cases. Second, the analysis indicates that vigorous judicial enforcement of the sacred norm against non pro rata distributions is necessary to block the attempts of majority shareholders to profit from self-dealing transactions with the corporation. Finally, with an expanded menu of enterprise forms, there is little cost in allowing the close corporation to maintain its distinctive qualities. Firms that are not waiting for the omelets to set can choose another form that allows easy exit of capital suppliers. 